\title{
Dissociation and the Unconscious Mind: Nineteenth-Century Perspectives on Mediumship
}

\section{Carlos S. Alvarado}

Parapsychology Foundation carlos@theazire.org

Submitted December 18, 2019; Accepted March 21, 2020; Published September 15, 2020

https://doi.org/10.31275/20201735

Creative Commons License CC-BY-NC

Abstract-There is a long history of discussions of mediumship as related to dissociation and the unconscious mind during the nineteenth century. After an overview of relevant ideas and observations from the mesmeric, hypnosis, and spiritualistic literatures, I focus on the writings of Jules Baillarger, Alfred Binet, Paul Blocq, Théodore Flournoy, Jules Héricourt, William James, Pierre Janet, Ambroise August Liébeault, Frederic W. H. Myers, Julian Ochorowicz, Charles Richet, Hippolyte Taine, Paul Tascher, and Edouard von Hartmann. While some of their ideas reduced mediumship solely to intra-psychic processes, others considered as well veridical phenomena. The speculations of these individuals, involving personation, and different memory states, were part of a general interest in the unconscious mind, and in automatisms, hysteria, and hypnosis during the period in question. Similar ideas continued into the twentieth century.

Keywords: mediumship; dissociation; secondary personalities; Frederic W. H. Myers; Théodore Flournoy; Pierre Janet

\section{INTRODUCTION}

Dissociation, a process involving the disconnection of a sense of identity, physical sensations, and memory from conscious experience, has been related to mediumship due to the latter's sensory and motor automatism and changes of identity. In recent years there have been some conceptual discussions of dissociation and mediumship (e.g., Maraldi et al., 2019) as well as empirical studies exploring their 
relationship (e.g., Vencio, et al., 2018). This is not a new interest, as seen in my discussion below of speculations and observations about dissociative aspects of mediumship during the nineteenth century. Considering some of this material has generally been forgotten by current mediumship and dissociation researchers, and that some of it has not been translated into English, my purpose in this article is to make the content of these writings more available, and to provide some historical context to current ideas on the subject with additional references, several of which appear in Notes. ${ }^{1}$

Readers should be aware that most of the discussions about the topic during the nineteenth century were attempts to reduce mediumship to psychological, physiological, and medical ideas. In addition, much of what I discuss as examples of dissociation was not seen as such by believers in the spiritual interpretation of mediumship.

\section{DISSOCIATION DURING THE NINETEENTH CENTURY}

\section{Trances and Secondary Personalities}

The concept of dissociation and of hidden levels of the mind was widely discussed throughout the nineteenth century in relation to manifestations such as amnesia, somnambulism, and secondary personalities appearing spontaneously or via hypnosis, and specific features such as state-specific memories (Crabtree, 1993; Gauld, 1992). For example, natural somnambulism, or sleepwalking, was discussed by many (e.g., Abercrombie, 1838; Bertrand, 1823; Macario, 1857; Prichard, 1835), and several cases were presented during the period (e.g., A., 1869; Abercrombie, 1838, pp. 296-298; Chambard, 1879; Moore, 1870). One of them was of a medical student who, in addition to having seen a patient,

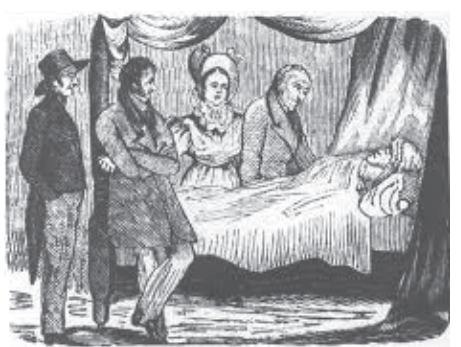

Figure 1. Rachel Baker, sleeping preacher (Smith, 1837) played the piano, played cards, and did anatomical drawings while he was in his somnambulistic state (A, 1869).

Many cases of somnambulistic behavior became well-known, such as that of American Rachel Baker (born 1794) (Figure 1), who preached to audiences about moral and religious topics with no recollection of her actions 
(Figure 1). "This modest damsel," wrote a commentator about her case, "falls into a devotional exercise as soon as she loses her consciousness" (Mais, 1814, p. 6). Interestingly, other cases of somnambulistic speakers were also reported during the nineteenth century (e.g., Belden, 1834; Mitchell, 1876). ${ }^{2}$

This was part of a long history of examples of "inspired," "entranced," or "somnambulistic" revelations about all kinds of topics, but particularly moral, philosophical, religious, and spiritual ones. Such cases came from antiquity and are to be found in the literatures of mesmerism, possession, religious movements, Spiritualism, trance, and other topics (e.g., Baxter, 1833; Casaubon, 1655; Gauthier, 1842; Oesterreich, 1930), which have also been discussed in more recent times (e.g., Crabtree, 1993; Garrett, 1987; Gauld, 1992; Taves, 1999). Examples of these "revelations" were the discourses of visionary and magnetic patient Friederike Hauffe (1801-1829) (Kerner, 1845), the mesmeric subject Emma (Haddock, 1851), and the well-known clairvoyant Andrew Jackson Davis (1826-1910) (Davis, 1847).

The mesmeric literature, embedded in the theoretical concept of animal magnetism, presented many examples of the induction of magnetic somnambulism. This was generally described as similar to sleep in some aspects:

If his magnetizer speaks to him he responds without waking up; he can even perform various movements, and when he returns to the natural state he retains no memory of what has happened. His eyes are closed, he usually hears only those who have been put in rapport with him. The external organs of his senses are all, or almost all, dormant, and yet he feels sensations, but by some other means. (Deleuze, 1825, p. 98) [This, and other translations, are mine.]

The state was interpreted by a writer to be one in between sleep and wakefulness (Gauthier, 1845, p. 566), while another mesmerist stated that it sometimes seemed to be a nervous disturbance, but in other occasions it appeared as a tranquil sleep (Charpignon, 1848, p. 67). English chemist and physician William Gregory (1803-1858) wrote in his Letters to a Candid Inquirer, on Animal Magnetism that: "The state 
of somnambulism is not a true sleep, but a state in which ordinary vision is cut off, while the mind is, in other respects, not only awake, but, intellectually and morally, more active than usual ..."(W. Gregory, 1851, p. 57).

Magnetic somnambulism, as seen in historical treatises (Crabtree 1993; Gauld 1992), was associated with phenomena such as thoughttransference, clairvoyance, healing, pre-vision of future events, and other occurrences. This is what German philosopher Carl du Prel (18391899) referred to as "new faculties, new connections with nature, in apparent contradiction with all the laws of physiology" (du Prel, 1907, p. 62).

Dissociative phenomena were discussed and observed as well by the mesmerists. Some of these reports can be found before the nineteenth century, such as Armand Marie Jacques de Chastenet Puységur's (17511825) Mémoires pour Servir à l'Histoire et à l'Établissement du Magnétisme Animal. Here he presented his now classic observations of Victor Race, a peasant he magnetized to treat his ailments. Described as quiet and shy, Race changed when magnetized. He became outspoken, and very friendly, "his heart poured out; . . as if it was filled with friendship \& gratitude..." (Puységur, 1784, p. 36).

French mesmerist Joseph Philippe François Deleuze (1753-1835) noticed that during the mesmeric state a person could recover the "recollection of things that were forgotten during wakefulness" (Deleuze, 1813, p. 176), leading him to postulate the existence of separate beings. Another interesting case was the patient Estelle L'Hardy, who showed various changes in the magnetic state (Despine, 1840). In addition to an apparent secondary personality and visions of someone called Angeline (among others), who "served as a guide to the patient" (p. 35), it was recorded that some of these changes were: "The remarkable development of intelligence, memory, imagination, and of all physical and moral faculties..." (Despine, 1840, p. 40).

Another mesmerist reported the case of a "magnetized" woman who referred to herself using a different name than usual, saying she was a different individual (Lang, 1843, pp. 95-96, 108). In addition, there were occasional reports of communications from the deceased (e.g., Lausanne, 1816, pp. 12-14). Louis Alphonse Cahagnet (1809-1885) presented many accounts of the spiritual world and of encounters 
with spiritual entities narrated by his mesmerized subjects in his Magnétisme: Arcanes de la Vie Future Dévoilés (Cahagnet 1848-1854; see also Haddock, 1851). Such accounts were believed by some to be the result of the influence of the magnetizer's interests and the somnambule's imagination (Sandby, 1850). ${ }^{3}$

Reminiscent of dissociative effects, mesmeric procedures could make people insensitive to pain, as seen in cases of amputations and removal of teeth (Elliotson, 1843; Esdaile, 1847). An interesting testimonial came from English writer of literature and social topics Harriet Martineau (1802-1876), who had a disease that caused her much pain that was alleviated by the use of opiates. She wrote in her book Letters on Mesmerism (Martineau, 1845) that once, when magnetized, she felt "a delicious sensation of ease spread through me,-a cool comfort, before which all pain and distress gave way, oozing out, as it were, at the soles of my feet" (p. 9).

Persons in the magnetic state have been described as forgetting events during their trance, but remembering them later during another magnetic induction. In this situation, according to Gregory, the person "lives ... a distinct life in the sleep, and has ... . a double or divided consciousness" (W. Gregory, 1851, p. 82).

In addition to mesmeric procedures, later explorers of hypnosis were able to document the existence of state-specific memories during their observations (e.g., Gurney, 1884). Some changes took place under hypnosis, as in the case of a woman named Lucie. When she was hypnotized it was noticed that the idea that appeared in her consciousness after a sudden awakening is not the recollection of somnambulism, it is the next part of the act started and interrupted during wakefulness. It is as if somnambulism never existed and the two waking moments seem to join. In the middle of a conversation L. was asleep before she could finish her phrase. After a quarter of an hour of sleep she woke up and calmly finished the conversation started without doubting that she had slept (Janet, 1886, p. 579).

So-called personalities were also induced through suggestion (Richet, 1883), leading to the speculation that suggestion could produce in the hypnotized a "dissociation of their psychic elements" (p. 233). This was sort of the illusion of being a different person, while maintaining their sense of self, which could disappear with a deeper 
hypnotic state. The process not only involved affecting recollections, but also an overstimulation of the person's imagination. Similarly, it was argued that suggestion could induce ideas of spiritual agency during automatic writing (e.g., Barkworth, 1891, p. 24).

This was part of an interest by the end of the nineteenth century on conducting psychology from an empirical perspective, as compared to philosophical speculations. Much of this took place, particularly in France, in studies of pathology of memory and other phenomena using the single case study approach (Carroy \& Plas, 1996; Foschi, 2003; Lombardo \& Foschi, 2003). It was assumed that much could be learned about the normal aspects of human beings by the study of their abnormalities (e.g., Ribot, 1885). The emphasis on pathology was the province of the work of individuals such as Jean-Martin Charcot (18251893) and Pierre Janet (1859-1947) (Bourneville, 1886; Janet, 1889). Others had a less pathologically oriented outlook, but still maintained that the induction of unusual mental states by hypnosis could illuminate the workings of the mind (e.g., Beaunis, 1885; Myers, 1886). As stated at the time, "throwing the mental machinery slightly out of gear" allows us to "discern the secrets of its adjustment" (Gurney \& Myers, 1885, p. 422).

Furthermore, much was learned about dissociation from those who studied motor automatisms (e.g., Binet, 1890; Binet \& Féré, 1887; James, 1889; Janet, 1889), and from cases of spontaneous secondary personalities. The latter included the cases of Mary Reynolds (17931854; Mitchill, 1817), Félida X. (born 1843) (Azam, 1887), Ansel Bourne (born 1826) (Hodgson, 1891), and Mollie

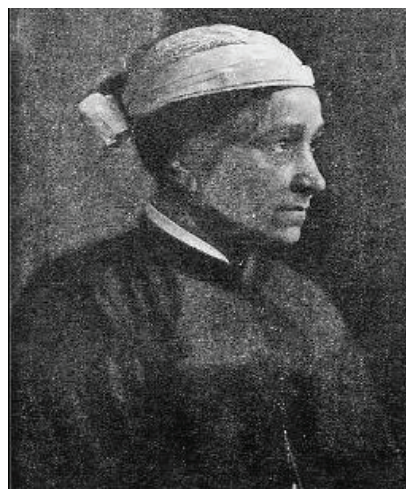

Figure 2. Léonie Leboulanger
Fancher (1848-1916) (Dailey, 1894), among many others (e.g., Bourru \& Burot, 1888; Dewar, 1823; Mason, 1893; Mayo, 1847, Chapter 18). 4

Some interesting observations of these personalities were those conducted under hypnosis with Léonie Leboulanger (born 1837) in France (Figure 2). When first hypnotized Léonie adopted the name Léontine, who claimed she was not Léonie: 
This new character, Léonie 2, claims to have all the sensations and all the actions, in a word, all the psychological phenomena she has been conscious of during somnambulism ... ; she attributes the opposite to Léonie 1, that is, to the normal awake person, all phenomena that have been conscious during wakefulness. (Janet, 1889, p. 132)

Cases of this sort, as well as many of the phenomena of hysteria and hypnosis, led some to speculation about the "doubling" of conscious thoughts. This, in the words of a student of the subject, suggested the existence of other aspects of the self "each of which may have its perceptions, its memories, and even its moral character" (Binet, 1891, p. 839). Furthermore, "there may exist successions of . . . intelligent, selfconscious operations that are accomplished without our help and even without our knowledge" (Binet, 1891, p. 855).

Eventually all of these phenomena, and others such as dreams, imagination, and memory, contributed to support the notion of the existence of non-conscious regions of the mind, and of dissociation. This was frequently discussed during the late nineteenth century in works such as On Double Consciousness (Binet, 1890), Das Doppellch (Dessoir, 1890), L'Automatisme Psychologique (Janet, 1889), The Psychology of Suggestion (Sidis, 1898), as well as in influential articles (e.g., James, 1890a; Prince, 1890).

These investigations coincided with the development of psychical research in the nineteenth century, as seen in countries such as Italy (Biondi, 1988), England (Gauld, 1968), the United States (Moore, 1977), France (Plas, 2000), and Germany (Wolffram, 2009). There is scholarly work showing that some of the studies of the unconscious mind, and the process of dissociation, not only took place within psychical research work, but that psychical research contributed to the development of these ideas (Alvarado, 2002; Crabtree, 1993; Plas, 2000). This was particularly the case in the study of mediumship, a phenomenon that played a central role in the development of Spiritualism in the nineteenth century (e.g., Cox, 2003; Edelman, 1995; Podmore, 1902), and that was pathologized by many students of the topic (Janet, 1889; Marvin, 1874). ${ }^{5}$ 


\section{Mediumship}

References to mediums include the assertion that they were "simply incomplete somnambules" (Perrier, 1854, p. 79), that they were "possessed with certain dominant ideas" (Carpenter, 1853, p. 547), that they showed a "mixed state" they were not aware of (Lafontaine, 1860, p. 31), and that trance made them automatons, liable to produce unconscious reflex actions (Beard, 1879).

Lawyer André-Saturnin Morin (1807-1888) wrote in Du Magnétisme et des Sciences Occultes that mediums had, like mesmeric somnambulists,

a mental state different from the waking state, and at times his opinions, his feelings, are seriously modified, so it is no wonder that the language he addresses the table with, bears a particular character that does not seem to belong to the person of the medium. (Morin, 1860, p. 368)

In this state, Morin assured us, it is not possible to distinguish if thoughts came from within or from outside the medium.

Another writer referred to suggestion bringing out the medium's "submerged personality" (Somers, 1893, p. 322). Others shared the belief that suggestion could condition the medium's subconscious mind to assume the shape of communications from the dead (e.g., Ermacora, 1893, pp. 42-43; Hudson, 1893, p. 213). This was the case even if the phenomena were veridical, a topic further discussed below.

American Judge John W. Edmonds (1799-1874), a medium himself, noticed that mediums sometimes were unaware that they were writing and knew nothing of the content of the written message (Edmonds, 1860). This was the case of Edmond's friend and writing medium, American physician George T. Dexter (Edmonds \& Dexter, 1853, p. 93), and of later mediums (e.g., Flournoy, 1900, p. 5; Myers, 1902, p. 70). Other variants of the experience of mediums witnessed by Edmonds were being conscious but with no control, and cases "when the medium was in the full possession of consciousness and volition, and yet was uttering the thoughts of an intelligence not his own" (Edmonds, 1860, p. 62). In fact, not every medium was entranced. As American reverend and spiritualist Samuel B. Brittan (circa 1815-1883) 
noticed, while performing many mediums are in their usual mental states, some "write letters and converse on subjects altogether foreign to the manifestations" (Brittan \& Richmond, 1853, p. 72).

The famous medium D. D. Home (1833-1886) described his experience of trance as follows:

I feel for two or three minutes in a dreamy state, then I become quite dizzy, and then I lose all consciousness. When I awake I find my feet and limbs cold, and it is difficult to restore the circulation ... I have no knowledge on my own part of what occurs during the trance. (London Dialectical Society, 1871, p. 188)

There are also accounts of Home behaving as if he were possessed by a spirit (e.g., L. M. Gregory, 1866). In one of them it was stated:

All who have seen Mr. Home in this state of trance, are aware how clearly he sees and communicates with spirits . . The gestures, the most trivial actions of bodily life, the mode of walking and speaking, the voice, the infirmities of persons who have passed away long before he was born, and concerning whose peculiarities in all these particulars Mr. Home had not the least possible means of obtaining any knowledge, are all repeated by him when in this state with an accuracy of detail which leaves no doubt, either that he is at the moment possessed by the spirit whose earthly characteristics he is delineating, or that he is receiving from them or from other spirits impressive communications which enable him to reproduce them. (D., 1867, p. 112)

Such experiences could vary, showing various degrees of trance (an ill-defined concept), and the production of phenomena without apparent alteration of consciousness (Edmonds, no date). There were even a few accounts showing awareness during trance (e.g., Hill-Tout, 1895).

An interesting introspective account about trance lectures comes from English medium and author Emma Hardinge (1823-1899), who 
stated in Six Lectures on Theology and Nature that when she talked to audiences inspired by spirits:

There is an absolute compulsion to perform a certain part, whilst I retain sufficient consciousness to appreciate and hopelessly to struggle against the control exercised. In these spiritual lectures I can equally clearly recognize the presence of psychological control. The unprompted flow of words is not my own. Every gesture and movement appears to me, at times, compelled, and yet the compulsion is accompanied by a dreamy indifference on my part, a perfect absence of care, and sense of safety and protection from my precious invisible masters, that renders my servitude an exceedingly happy one ... The details of my addresses I can only realize very imperfectly at the time, my own state being too dreamy for acute perception. (Hardinge, 1860, pp. 11-12)

Another account, this one about automatic writing, showed no awareness of the process. For example, the above-mentioned writing medium George T. Dexter wrote: "Let it also be understood that the spirit-manifestation by my arm is absolutely involuntary. I have no direction in the act. My muscles are the medium of spiritcommunication, not my thought..." (Edmonds \& Dexter, 1853, p. 89).

One writer referred to common characteristics of the secondary mediumistic personalities. In addition to claims to be a spirit, the list included suggestibility, eloquence, enhanced memory and imagination, and a propensity for vulgarity and profanity (by no means universal), and there was "a certain faculty of lucky or supernormal perception" (Patrick, 1898, p. 559), something the writer was skeptical of.

Much was written about veridical information obtained through mediums, which did much to sustain the belief in the reality of spirit communication (e.g., Cridge, 1854, Chapter 8; Moses, 1879). Physician William Gregory, said that although mediums believed that their communications came from spirits of the dead, he thought that "being more or less somnambulists and lucid, these answers come from their own intelligences, but without any consciousness of this fact" (W. Gregory, 1856, p. 320). Another defender of living agency was physician 


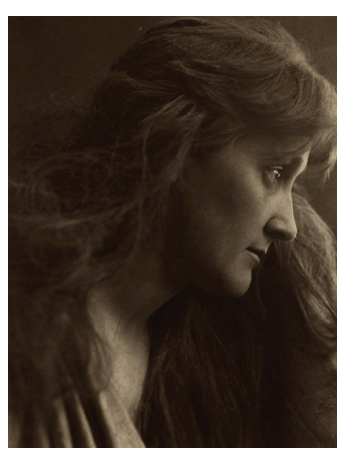

Figure 3. Leonora E. Piper
Carl Gustav Carus (1789-1869), who said in Über Lebensmagnetismus (1857) that mediumistic communications were phenomena that source the medium's unconscious divining powers (Carus, 1857).

The veridical trances and behavior changes of American medium Leonora E. Piper (18571950) (Figure 3) were particularly influential (e.g., Hodgson, 1892, 1898; James, 1886; Lodge, 1890). ${ }^{6}$ One of her investigators wrote:

The personality active and speaking in the trance is apparently so distinct from the personality of Mrs. Piper that it is permissible and convenient to call it by another name ... It strikes one as a different personality altogether, and the name by which it introduces itself when asked, viz., "Dr. Phinuit," is as convenient as any other ... and can be used wholly irrespective of hypothesis ... At the same time the name is useful as expressing compactly what is naturally prominent to the feeling of any sitter, that he is not talking to Mrs. Piper at all. The manner, mode of thought, tone, trains of idea, are all different. You are speaking no longer to a lady but to a man, an old man ... (Lodge, 189o, p. 448)

Changes of behavior consistent with the identity of spirit communicators were observed with many mediums. In the opinion of an early author, automatic actions in the brain could allow a medium to "assume any personality, from that of a divinity to that of a toad" (Rogers, 1853, p. 171). In one case a medium "was first controlled by an influence which purported to be the spirit of Pocahontas, during which she combed her hair down upon her shoulders, and assumed the actions and even the physiognomy of an Indian woman, and sang what appeared to be an Indian song" (Anonymous, 1854, p. 202). Another example with the medium Emma Jay, recorded in the well-known book From Matter to Spirit, was the observation that "her voice and manner differed much when under different influences" (De Morgan, 1863, p. 90). ${ }^{7}$ 
Those types of observations led Russian Alexander Aksakof (18321903) to discuss the "doubling of consciousness" as a fundamental phenomenon of mediumship (Aksakof 1895/1890, p. xxiv). This included the phenomenon of personation, which shows the "duality of the psychic being" (p. xxiv) presenting an unconscious life. In mediumship and other phenomena, this author stated, the self "can have a multiple character-normal, abnormal, or fictional-according to the conditions of the organism (natural sleep, somnambulism, mediumship)" (p. xxiv).

This has led to many discussions about the topic. Among them, those concerning the similarities between secondary personalities in non-mediumistic cases and the communicators and controls manifested by mediums (e.g., Leaf, 1890, p. 567).

Also relevant to the concept of dissociation in mediumship were various ideas of unconscious action in mental and physical mediumship, including the reality of the manifestations, and which were akin to the concept of unconscious cerebration (e.g., Lum, 1873; Rogers, 1853). In addition, there were ideas of unconscious muscular action to account for table turning (e.g., Braid, 1853; Faraday, 1853). ${ }^{8}$

\section{FURTHER EXAMPLES OF DISCUSSIONS OF MEDIUMSHIP AND DISSOCIATION}

\section{Paul Tascher}

The topic was discussed in Paul Tascher's (1855) Seconde Lettre de Grosjean à son Évèque au Sujet de Tables Parlantes, des Possessions, des Sibylles, du Magnétisme et Autres Diableries, published anonymously under the pseudonym Gros Jean. Tascher's ideas have been popularized by later authors (e.g., Crabtree, 1993, pp. 264-265; Janet, 1889, Part 2, Chapter 3, Section 4). He believed that in adolescence, and in the case of young girls, there may be a separation of the action of the will on the body, affecting sensibility and recollections, which could be manifested in mediumistic ways. He wrote about table turning and mediumship and listed five stages of the process.

In the first stage, Tascher wrote, the will and the sense of self were not separated. This separation commenced in the second stage in which the young person's will started to separate from the mind and the body, and could act without willful action (automatism). Writing, 
speech, and movements of the table (with contact) started to take place in the third stage: "The girl knows the answer that forms in her intellect, but she knows it as if it did not come from her: Attention is engaged, but without establishing the link between the mind and the self" (p. 11).

Finally, Tascher wrote about the fourth stage:

The girl has no internal knowledge of the response that is made in her mind, apart from the self; she does not know that as the movements of the table take place: the mental division is complete.

At the same time dissenting thoughts increase their domain. It is no longer a question addressed to the table, to the contrary she spontaneously interrogates one or other of the persons present ... distant recollections are revealed without the girl's awareness, romantic inventions, sentimental fantasies, ramblings [are produced] ... (Tascher, 1855, pp. 10-11)

\section{Jules Baillarger}

Other interesting comments were authored by French physician Jules Baillarger (18091890) (Figure 4), well-known for his studies of mental illness and one of the founding members of the Société Médico-Psychologique (Ritti, 1891). His short comments were published in the Annales Médico-Psychologiques in the context of a presentation made at the aforementioned society on February 27,1860 , in which it was assumed that mediumistic practices could lead to mental illness, an idea shared by many French psy-

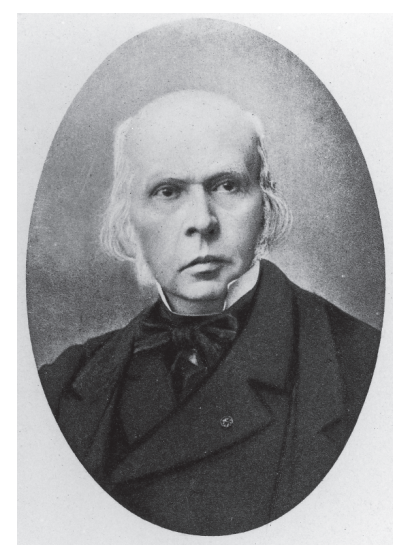

Figure 4. Jules Baillarger chiatrists (Le Maléfan, 1999).

Baillarger wrote about a woman who believed she was in contact with her deceased daughter, to whom she spoke continuously. The lady claimed the daughter guided her. According to Baillarger: "There is a doubling of personality similar to that which occurs during a dream; a fraction belonging to the individual, it seems there is another outside her" (Baillarger, 1861, p. 93). 


\section{Hippolyte Taine}

French historian and critic Hippolyte Taine (18281893) (Figure 5) is by all accounts an important figure in the development of positivistic approaches to knowledge in nineteenth century France (Nias, 1999). In his book De l'Intelligence (1878), he referred to a person's internal dialogue and abolition of the senses and of functions. Furthermore, Taine stated:

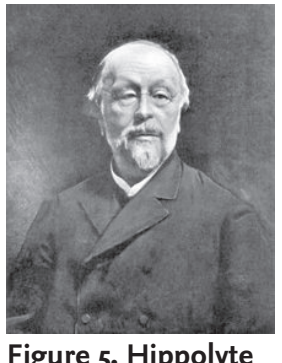

Taine

In this respect, the spiritist manifestations themselves put us on the path of discovery, showing us the coexistence at the same time, in the same individual, of two thoughts, two wills, two different actions, one of which is conscious, the other of which he is unaware of and which he attributes to invisible beings. The human brain is then a theatre in which different plays are performed at the same time... Nothing is more worthy of study than this basic plurality of the self; it goes much further than we imagine. I have seen a person who, [while] talking, singing, wrote, without looking at the paper, phrases and even entire pages, without been aware of what she wrote. In my eyes, her sincerity is perfect: She says that after the last page she has no idea of what she has written on the paper; when she reads it, she is surprised, sometimes alarmed. The writing is different from her ordinary writing. The movement of the fingers and the pencil is stiff and seems automatic. The writing always ends with a signature, that of a dead person, and bears the imprint of intimate thoughts, of a mental background that the author does not want to disclose.-Certainly we observed a doubling of the self, the simultaneous presence of two series of parallel and independent ideas, two centers of action ... juxtaposed in the same brain, each with its own work and each with different work, one on stage and the other behind the scenes, the second as complete as the first, since, alone and out of sight of each other, they build ideas followed and linked with phrases and related sentences which the other has no part of. (Taine, 1878, pp. 16-17) 


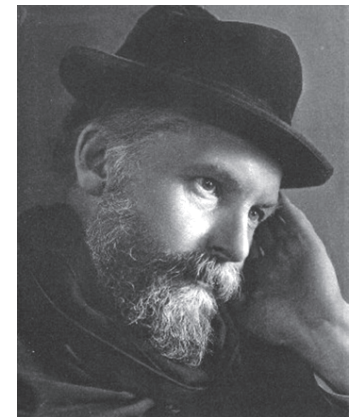

Figure 6. Frederic W. H. Myers

\section{Frederic W. H. Myers}

An example of an influential theorist, mainly in psychical research, but also in psychology, was classical scholar Frederic W. H. Myers (1843-1901) (Figure 6). ${ }^{9}$ In his view, there were a variety of states and conditions affecting the threshold between the conscious and unconscious (or subliminal) regions of the mind. These included dreams, hypnosis, hysteria, mediumistic trance, natural somnambulism, and some medical conditions, which could "afford examples of the development of what I have called secondary mnemonic chains,- - fresh personalities, more or less complete, alongside the normal state" (Myers, 1888, p. 387).

Myers wrote about automatic writing stating, that there were many cases in which the person produced writing without being aware of its content. On occasion, "the involuntary movement of the pen is altogether puzzling to the writer,-is something which he has to make out with difficulty as if it were the product of another brain ..." (Myers, 1884, p. 226; see also Myers, 1885).

In Myers' view the trance utterances of medium Mrs. Piper were automatisms "which occur in sane subjects without entering the normal waking consciousness or forming part of the habitual chain of memory" (Myers, 1890, p. 437). It was for him, as he wrote in his wellknown work Human Personality and Its Survival of Bodily Death (1903), an extreme case of automatism affecting "the whole psychical area;where a secondary consciousness not only crops up here and there through the primary, but for a time displaces it; - where, in short, the whole personality appears to suffer intermittent change" (Myers, 1903, Vol. 2, p. 237).

Possession in mediumship, Myers (1903) believed, was akin to apparent possession by one own's subliminal self, as seen in some cases of creativity and hypnotic secondary personalities. In this way Myers saw a continuity of the action of the subliminal mind and dissociation that was not limited to mediumship.

While Myers accepted spirit communication via mediumship 
(e.g., Myers, 1902), he believed that, even with the best mediums, not all trances came from spirits, and that the medium's mind could interact with spiritual influence. He wrote: "I think that the depth of the trance has varied greatly on different occasions, and that sometimes the subliminal self of the sensitive is vaguely simulating, probably in an unconscious dream-like way, an external intelligence" (Myers, 1903, Vol. 1, p. 205). Such dynamics of the subliminal accounted for the mixed source of messages, which could be further complicated, Myers thought, by the content of the medium's supraliminal (conscious) mind. Furthermore, Myers (1903, Vol. 2, p. 250) conceived of "a kind of mixed telepathy between the sitter, the sensitive's spirit, and the extraneous spirit," which could appear during the same séance. ${ }^{10}$

In addition, Myers also observed varieties in the trance and behaviors of Mrs. Piper during séances. The spirit control "Phinuit" sometimes was fairly quiet. At times no veridical information was given, while at other times it seemed to flow freely. Also:

The trances could not always be induced at pleasure. A state of quiet expectancy would usually bring one on; but sometimes the attempt altogether failed. The trance when induced usually lasted about an hour, and there was often a marked difference between the first few minutes of a trance and the remaining time. On such occasions almost all that was of value would be told in the first few minutes; and the remaining talk would consist of vague generalities or mere repetitions of what had already been given (Myers, 1903, Vol.

2, p. 239).

\section{Eduard von Hartmann}

In Germany philosopher Eduard von Hartmann (1842-1906) (see Treitel, 2004, pp. 13-15, 21-22) believed that mediums had a "a certain disorganization of the nervous system; that is, the lower and the middle nerve centres are too independent of the highest, reflex-prohibiting centre of consciousness self control; they are, in other words, . . . hysterical . . . ." (von Hartmann, 1885, p. 406). Mediums, according to him, showed two forms of somnambulism, an automatic one, with no 
intelligence, and an intelligent one.

The somnambulistic consciousness, he believed, had a tendency to form personalities. "A medium in the somnambulistic state can play the part of a spirit and do things of which afterwards, when awake, he knows nothing, and which from the reports of the witnesses he must take for immediate spirit actions" (von Hartmann, 1885, p. 5).

This could involve veridical information. But according to von Hartmann these unconscious processes could also guide physical mediumship via the exteriorization of the medium's nervous forces. ${ }^{11}$ In his view:

This liberation of directive radiation of nerve force is under all circumstances ... not a function of those parts of the brain which serve as support to the conscious will, but of deeper-lying layers of the brain which either coincide with those supporting the somnambulic consciousness, or are more approximate to them than to the first. (von Hartmann, 1885 , p. 442)

\section{Charles Richet}

The famous physiologist Charles Richet (18501935) (Figure 7) was also well-known during the nineteenth century for his work in psychical research, particularly his studies of what we would refer to today as ESP (e.g., Richet, 1884, 1889) (on Richet, see Alvarado, 2019a, and S. Wolf, 1993). In the 1884 article, the classic "La Suggestion Mentale et le Calcul des Probabilités," he wrote about mediumship and dissocia-

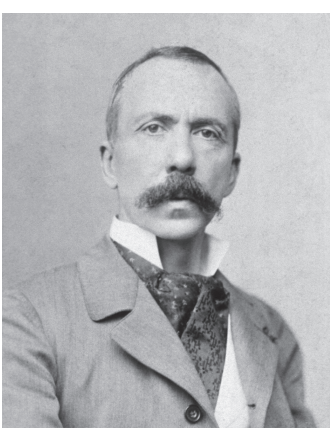

Figure 7. Charles Richet tion, expressing his belief that

all the intelligent manifestations attributed to the spirits are due to an individual that is unconscious and active at the same time. In addition, he is surprised by everything produced; because he is ignorant of the intellectual operations he performs, which are translated into action, and are not less removed from his awareness. (Richet, 1884, p. 650) 
Richet stated that some individuals could perform actions without conscious awareness. The medium, he thought, was a person "who has the ability of hemisomnambulism or partial unconsciousness, an ability by which a part of his intelligence, his memory, his will, operates outside of awareness, however, consciousness remains quite awake" (Richet, 1884, pp. 650-651).

In a later paper, entitled "Les Mouvements Inconscients," Richet said that in mediums

two states succeed each other and are mixed, that is, regular normal consciousness persists at the same time as another consciousness appears, coinciding with it without mixing, performing acts exempted from the first normal consciousness, and continuing, without the aid of the normal consciousness, a series of logical developments. It is therefore hemi-uncon-sciousness, or hemi-somnambulism.

(Richet, 1886, p. 93)

Richet eventually defended the reality of veridical mediumship, as I point out at the end of this paper.

\section{William James}

American psychologist and philosopher William James (1842-1910) (Figure 8), well-known for his interest in psychic phenomena, also contributed to the study of mediumship (Alvarado, 2016; Knapp, 2017). Writing in Scribner's Magazine, James (1890a) summarized the work of French researchers on dissociative states. In his view trances were not necessarily pathological and were far from understood. He wrote: "A com-



Figure 8. William James parative study of trances and sub-conscious states is meanwhile of the most urgent importance for the comprehension of our nature" (W. James, 1890a, p. 373). 
When James discussed automatic writing in his Principles of Psychology, he stated:

The lowest phase of mediumship is automatic writing . . . Inspirational speaking, playing on musical instruments, etc., also belong to the relatively lower phases of possession, in which the normal self is not excluded from conscious participation in the performance, though their initiative seems to come from elsewhere. In the highest phase the trance is complete, the voice, language, and everything are changed, and there is no after-memory whatever until the next trance comes. (W. James, 189ob, pp. 393-394; see also W. James, 1889)

Also in Principles, James considered the similarities between many spirit communications and wondered if "sub-conscious selves are peculiarly susceptible to a certain stratum of the Zeitgeist, and get their inspiration from it," something which "is obviously the case with the secondary selves which become 'developed' in spiritualist circles" (W. James, 189ob, p. 394). Nonetheless, he was not willing to explain all the content of communications using that explication. ${ }^{12}$

In various papers, James (1886, 1890c, 1909) reported his observations of medium Leonora E. Piper, who eventually convinced him her mentation could be veridical. He wrote that he was "as absolutely certain as I am of any personal fact in the world that she knows things in her trances which she cannot possibly have heard in her waking state, and that the definitive philosophy of her trances is yet to be found" (W. James, 189oc, pp. 658-659). But James also wrote that, regardless of showing good memory of previous communications, "Phinuit," the medium's spirit control, appeared to him to be fictitious. On occasion, James complained, he produced "tiresome twaddle" (W. James, 189oc, p. 656).

The importance of James' (1886) earlier Piper report has been pointed out elsewhere (Alvarado, 2016). In addition to being the first scientific study of a mental medium (and of Piper) published, this was a call for the study of special individuals, ${ }^{13}$ and an example of the innovative use of stenographic records for that purpose. More relevant 
for the topic of dissociation, James paid attention to the features of Piper's trances (which unfortunately he did not describe in the report), and used hypnosis to study them.

Regarding hypnosis, James (1886) wrote about his modest results:

My first two attempts to hypnotize her were unsuccessful. Between the second time and the third, I suggested to her "Control" in the medium-trance that he should make her a mesmeric subject for me. He agreed. (A suggestion of this sort made by the operator in one hypnotic trance would probably have some effect on the next.) She became partially hypnotized on the third trial; but the effect was so slight that I ascribe it rather to the effect of repetition than to the suggestion made. By the fifth trial she had become a pretty good hypnotic subject, as far as muscular phenomena and automatic imitations of speech and gesture go: But I could not affect her consciousness, or otherwise get her beyond this point. Her condition in this semi-hypnosis is very different from her medium-trance. The latter is characterized by great muscular unrest, even her ears moving vigorously in a way impossible to her in her waking state. But in hypnosis her muscular relaxation and weakness are extreme. She often makes several efforts to speak ere her voice becomes audible; and to get a strong contraction of the hand, for example, express manipulation and suggestion must be practised. The automaticimitations Ispoke of areinthefirstinstanceveryweak, and only become strong after repetition. Her pupils contract in the medium-trance. Suggestions to the "Control" that he should make her recollect after the trance what she had been saying were accepted, but had no result. In the hypnotic-trance such a suggestion will often make the patient remember all that has happened. (W. James, 1886, pp. 105-106) $)^{14}$

While Piper showed some evidence of veridical communications that impressed James, she was not consistently successful in thoughttransference tests conducted in her normal state, during hypnosis, or during her mediumistic trance. 
In a later publication by James (1909), "Report on Mrs. Piper's Hodgson-Control," he presented more examples of trances and communications via Piper by the presumed personality of Richard Hodgson (1855-1905), one of the medium's main investigators while he was alive. Referring to Rector, a later spirit control, he wrote:

He appears like an aged and, when he speaks instead of writing, like a somewhat hollow-voiced clergyman, a little weary of his experience of the world, endlessly patient and sympathetic, and desiring to put all his tenderness and wisdom at your service while you are there. (W. James, 1909, p. 3)

James also commented about how lifelike the conversations with Rector and Hodgson could be, a feeling not possible to obtain by reading the transcripts. He discussed how difficult it was for him to decide if the drama presented by Piper was from a spirit source, or the result of psychological personation, perhaps with flashes of telepathy. This fascinating discussion presents a good example of how dissociative processes and spirit agency permeated the theoretical thoughts of some psychical researchers.

At the end of the Hodgson report, James wrote that he felt there was a will to communicate that went beyond telepathy. "But if asked whether the will to communicate be Hodgson's, or be some mere spirit-counterfeit of Hodgson, I remain uncertain and await more facts, facts which may not point clearly to a conclusion for fifty or a hundred years" (W. James, 1909, p. 121).

\section{Pierre Janet}

When it comes to dissociation, the above-mentioned psychopathologist Pierre Janet (Figure 9), who was also interested in psychic phenomena, was one of the central figures of the nineteenth century (Evrard et al., 2018; Nicolas, 2002, Chapter 7; Van der Hart \& Horst, 1989). In a reference to automatic writing, Janet (1887) stated that this

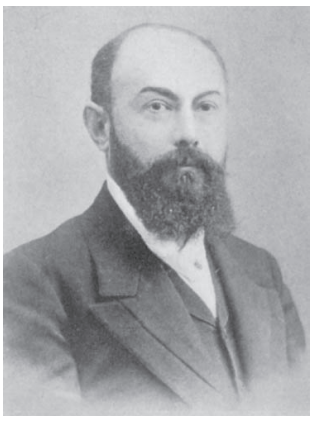

Figure 9. Pierre Janet 
phenomenon represented the separation of some psychological aspects of the mind that are "grouped in a new synthesis that has the appearance of a personality" (p. 452). This practice common in mediums, he believed, was a "way... to penetrate further into the thoughts of somnambules" (Janet, 1886, p. 452).

In L'Automatisme Psychologique, published in 1889, Janet discussed various phenomena such as automatisms, hypnotic memory, and mediumship (on Janet and mediumship, see Le Maléfan, 1999, pp. 6684). ${ }^{15} \mathrm{He}$ argued that when someone was psychological healthy their synthesis of mental functions such as memory was cohesive, but that the opposite was the case when unhealthy conditions predominated. This produced a state of "disaggregation" (or dissociation) that could be part of hysteria and other conditions, presenting changes of personality, and the above-mentioned memory and sensory-motor disturbances. The person would be more sensitive to suggestion, and to other manifestations, among them catalepsy and automatic writing. "This is the state in which spiritists are so happy to see their mediums in order to evoke the spirits through the disaggregated phenomena" (Janet, 1889, p. 338). Because he believed that automatic activity and dissociation in general were inferior mental manifestations (see also Beard, 1879, and Hammond, 1876), mediumship was consequently pathologized (see Note 5).

Janet wrote that most mediums "are neuropaths, when they are not frankly hysterics" (Janet, 1889, p. 404). Furthermore, he said that "we see from time to time that the medium has some choreic movements ..., or that the experience of automatic writing causes them great exhaustion which forces them to stop because of delicate health ..." (p. 405). ${ }^{16}$

Janet believe that changes in the writing of the hypnotized and of mediums were of the same nature, and that both showed "the disintegration of personal perception" as well as "the formation of several personalities which sometimes succeed and sometimes develop simultaneously" (Janet, 1889, p. 413). He stated that "perfect" or fully dissociated mediums showed "the most complete type of division in which the two personalities are completely unaware and develop independently of each other" (p. 419).

In later writings Janet continued discussing the topic (Janet, 1892, 
1904; Raymond \& Janet 1908). "The medium," he wrote in Névroses et Idées Fixes, "is an individual who dreams while awake, but who has completely lost the personal consciousness of his reverie" (Janet, 1904, pp. 394-395). Such a person is unaware of the things he has said or written, which are attributed to a deceased spirit, and sometimes to a famous one. He also maintained that in some mediums automatic writing was accompanied by a "temporarily anesthesia of the hand and even an anesthesia of hearing" (Raymond \& Janet, 1908, p. 404). ${ }^{17}$

\section{Jules Héricourt}

"The state of the problem of the unconscious," wrote Hen ri F. Ellenberger in his well-known work The Discovery of the Unconscious (1970), "as it was in the late 1880 s, was sketched by Héricourt in a survey published in 1889, stating that the unconscious activity of the mind is a scientific truth established beyond any doubt. ..." (p. 314). This was a reference to French physician Jules Héricourt (1850-1938), who distinguished himself in military medicine, serotherapy, hygiene, tuberculosis, and other areas (on Héricourt, see Anonymous, 1914). Interestingly, but similar to some of his colleagues at the time, Héricourt was also interested in psychic phenomena (e.g., Héricourt, 1886).

The paper in question, entitled "L'Activité Inconsciente de l'Esprit," was published in the French journal Revue Scientifique, a publication edited by Charles Richet that was devoted to discussions of developments in all areas of science (Héricourt, 1889). The article was a review of some of the phenomena considered to provide evidence for the workings of the unconscious mind, considering such topics as hysteria, hypnosis, and cases of spontaneous secondary personalities. In addition, Héricourt considered mediumship.

Mediumship, our author wrote, presents a state of trance in which "the conscious and the unconscious appears to have an independent existence, not successive, but simultaneous" (p. 265). In automatic writing the medium may write without showing awareness of what he or she is doing. In his view

some mediums, in the state of trance, completely have the appearance of somnambules or of hypnotized subjects; and, 
in fact, one can observe in them all the degrees between a kind of hemisomnambulism, as Mr. Richet well named the state of mediums who were awake, and the state of complete somnambulism. (Héricourt, 1889, p. 265)

Conscious mediums feel, wrote Héricourt, that the medium's writing is produced by a deceased spirit. It is a real foreign personality to the conscious medium, but one in which the unconscious mind communicates to the conscious mind without the latter's awareness. "This second personality is most frequently a simpleton and extremely childish, but sometimes, on the contrary, it shows a true originality and a memory and a subtleness of which the conscious person seems completely deprived ..." (Héricourt, 1889, p. 265).

Héricourt concluded:

The conditions of mediumship are still rather badly known. However, it seems that the aptitude for somnambulism and for suggestions is a very favorable condition. The preparation of the medium with its exercises can also explain the nature of the results obtained. Such preparation consists, indeed, in a kind of auto-hypnotization which takes the subject midway between the waking state and the state of complete hypnotism. The unconscious person appears without the conscious person, whose disintegration undoubtedly relates only to a few elements, which have disappeared or are greatly reduced. It is the hemisomnambulism of Mr. Richet (Héricourt, 1889, pp. 265-266).

\section{Ambroise August Liébeault}

Another French physician who contributed to ideas about mediumship and dissociation was Ambroise August Liébeault (1823-1904) (Figure 10), well-known for his influence on the Nancy school of hypnosis through his psychotherapeutic use of suggestion (on Liébeault, see Carrer, 2002, and Gauld, 1992, pp. 319-324). In addition, he was interested in psychical

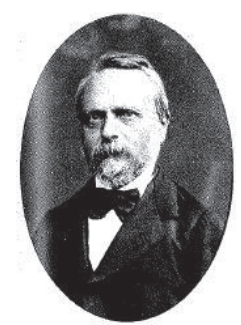

Figure 10. Ambroise August Liébeault 
research topics (Alvarado, 2009).

Liébeault (1889) stated in his book Le Sommeil Provoqué et les États Analogues that people could answer their own questions without awareness when in hypnotic states. This was an explanation for table turning, generally explained by the action of spirits. Those acting as mediums around tables, he wrote, were in a mental state analogous to that of the dreamer who believes in unreal characters as long as he is not awake.

In Liébeault's view mediums and the hypnotized were similar. He wrote that both of these individuals do not show any difference in their passive state: Concentration of thought to enter their dreams in action, isolation, automatism, insensibility, loss of memory upon awakening, all these signs are common to them; but the medium, entering his dream with the idea that he will remember the revelation of spirits and their appearance, keeps more often than the somnambule the memory of the acts of his passive state (Liébeault, 1889, p. 250).

\section{Paul Blocq}

Physician Paul Blocq (1860-1896), once at the Salpêtrière, and a researcher of various aspects of internal medicine and neurology (Walusinski, 2014), believed that automatic writing produced by mediums and non-mediums, such as hysterics, were similar. Both, he stated in his article "L'Écriture Médianimique.-Le Spiritisme au Point de Vue Scientifique," involved lack of awareness of producing writing (Blocq, 1889).

Spiritists beliefs in discarnate agency, Blocq stated, could be questioned on the basis of the content of spirit communications. "Massillon lost his eloquence, Mozart his genius, and a good number of other no less illustrious people expressed themselves in a coarse, sometimes incomprehensible way, committing inadmissible anachronisms" (Blocq, 1889, p. 1436). He believed that such communications were produced unconsciously by the medium.

The process involved suggestions given by the sitters, and recollections from the medium's memories. "On the occasion of special influences, memory takes, as we know, an extraordinary acuteness: Its abnormal development means that in the medium, the facts, usually completely forgotten, come back as a precise memory that will animate their pen" (Blocq, 1889, p. 1436). Blocq believed that "some hysterical 
states, and hypnotic somnambulism in particular, come close to becoming confused with the psychic disposition which characterizes the state of the medium" (p. 1437).

\section{Alfred Binet}

French psychologist Alfred Binet (1857-1911) (Figure 11), is well-known for his studies of hypnosis, intelligence, and other topics (on Binet, see Alvarado, 2010; Nicolas \& Ferrand, 2002; T. H. Wolf, 1973). He discussed dissociation in some of his writings (e.g., Binet, 1889, 1890). In one article he commented that

mediums "manage to express in a variety of Figure 11. Alfred Binet ways, and often without being aware of it, a

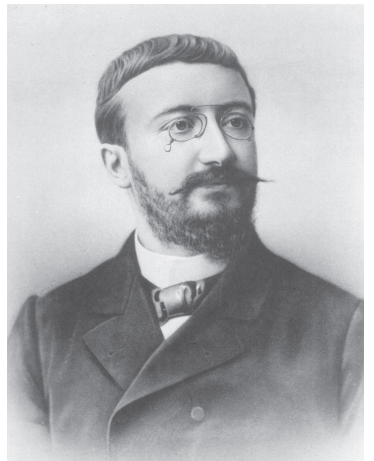
thought which is not theirs" (Binet, 1891, p. 852). In automatic writing, Binet continued, the medium presents thoughts outside of conscious awareness. There are "two coexisting personalities; because the thought that directs the automatic writing is not a disjointed thought, it has a character of its own, and even has a name, the name given to the spirit that has been evoked" (Binet, 1891, p. 854).

In a book about alterations of personality, Binet (1896/1892) wrote about mediumship. The book had three sections about various phenomena of dissociation such as spontaneous secondary personalities, hysteria, automatic writing, and alterations of personality using suggestion. As before, Binet affirmed that in automatic writing via mediumship there were two coexistent personalities.

Furthermore, in his view:

As with experiments in suggestion, those in spiritism succeed best on a certain class of subjects, among whom hysterical patients hold an important place. Hysterical patients, and somnambulists generally, furnish the greater part of the good mediums. One may see that by glancing over the works on spiritism. Every now and then the most discreet author finds himself obliged to say that such and such an excellent medium had a nervous crisis or was soon fatigued, in consequence of delicate health. It is, moreover, generally 
admitted that spiritist performances predispose to nervous complications. (Binet, 1896/1892, pp. 229-230)

Binet also stated that mediumship also presented a tendency toward personation, believed by many to be spirits of the deceased (see Note 7). "In any case this person does not consider himself as a part of the medium, and does not apply his special memories to the medium" (Binet, 1896/1892, p. 339). Personation, Binet stated, is affected by expectations from the medium, or communicated to her from sitters at a séance. Discussing this in more detail, Binet wrote that it was the secondary self who performed the suggestion, "and who, sustaining this illusion or obligingly complying with it-for we do not know exactly how it occurs-goes on to write messages in the style of the person conjured up, whose name he signs" (Binet, 1896/1892, p. 340).

It is this suggestion, Binet postulated, that led to a dissociated state. Eventually, this caused the emergence of a subconscious personality.

\section{Julian Ochorowicz}

Polish philosopher Julian Ochorowicz (1850-1917) (Figure 12) was a philosopher and psychologist of many interests, including hypnotism and psychical research (Hess, 2018; Weaver, 2019). Among other things, he was an inventor, published on mental suggestion and physical mediumship (e.g., Ochorowicz, 1887, 1910), and was also interested in unusual mental states, Figure 12. Julian Ochorowicz such as dissociation.

This interest is clear in "La Question de la Fraude dans les Expériences avec Eusapia Paladino," a paper authored by Ochorowicz (1896) about fraud in séances with the famous Italian medium Eusapia Palladino (1854-1918), well known for her séances for physical phenomena such as movement of objects, touches, lights, and materializations. ${ }^{18}$ The paper is basically a critique of the attitude taken by researchers from the Society for Psychical Research in their 
investigation of Palladino ( $\mathrm{H}$. Sidgwick, 1895; see also Gauld 1968), but it contains much about mediumship and dissociation.

In that investigation, Ochorowicz wrote, the researchers "did not admit in their report but two alternatives: real phenomena, and conscious fraud" (Ochorowicz, 1896, p. 96). He criticized them on the basis that they did not consider unconscious fraud. This form of fraud, Ochorowicz believed, was commonly practiced by Palladino in her séances, and it was a manifestation of what he considered to be inferior mediumship, as compared to superior mediumship, consisting of true physical phenomena. ${ }^{19}$

The English researchers, he wrote further, did not make sure that she was in trance, a state which facilitated unconscious fraud. This was a problem when they accused Palladino of premeditated fraud, a fraud she would not remember consciously. Part of this consisted of bodily movements which may have been "motor representations that rule in a given moment the medium's imagination" (Ochorowicz, 1896, p. 100, italics in the original).

To support his belief in Palladino's dissociative actions, Ochorowicz recounted an experience he had with the medium while she was visiting Warsaw for a series of séances. Everyone had turned in to sleep, when he saw in darkness that the medium, who was in a nearby room to that where he was with his wife, entered their room and opened and closed a drawer of his wife's dressing table. Then she left silently. They went to her room and found her in bed, apparently sleeping. She woke up and denied having been in the other room, a denial that continued the next day when asked about the incident again.

Ochorowicz, who believed that Palladino was in a somnambulistic state, decided to use table tilting to question the medium's spirit control about the incident. The improvised séance, with the medium out of trance, revealed, to Palladino's surprise, that she had in fact been in Ochorowicz's room looking for matches, and that she was neither in her normal nor trance state, but sleepwalking. This is a woman, Ochorowicz wrote, "who is capable to be in an entirely different psychic state from one moment to another" (Ochorowicz, 1896, p. 102).

Ochorowicz argued that at the beginning of a séance the medium produced inferior phenomena (automatisms leading to fraud), so she needed some time before every séance to go deeper into "physiological 
doubling" (dissociation) to produce real phenomena. This involved separation between the medium's brain and her nervous centers and separation from the "dynamism" of her bodily limbs. Ochorowicz wrote:

Before arriving at this last point, which constitutes the node of higher mediumship, the medium must necessarily cheat, because she is not aware of the position of her members, which sometimes become hyperesthetized and insensitive, or of the difference that there is between a movement performed remotely and a direct movement, since this is always her arm, sometimes palpable and sometimes impalpable, executing the ordered movement. Gradually the doubling increases, subjective differences are accentuated, and then we can be expected to watch her reflexes; her hand, which naturally seeks to free itself and to follow the direction of her thoughts, does not go too far in that direction, and does not execute the movement herself. (Ochorowicz, 1896, pp. 109-110)

Without any influence to contradict these factors, Ochorowicz affirmed, "the medium will always cheat" (Ochorowicz, 1896, p. 107).

Ochorowicz saw the phenomena of Palladino as produced by psychic forces related to the medium and the sitters (on this concept see Note 11). He believed that John King, the medium's spirit control, was a "special psychic state that allowed the vital dynamism of the medium ... to act out at a distance in certain exceptional conditions" ( $p$. 104). In his view the action of the spirit control could change according to the suggestive influences of the circle. As he wrote:

After recognizing that the medium is only a mirror that reflects and directs the ideas and nerve forces of the sitters towards an ideoplastic goal, ${ }^{20}$ we will not be surprised to see that suggestion plays an important role. It is not doubtful that the sitters can suggest to the medium the desired act, and there is no doubt that manifestations take on the character of the surrounding beliefs. I have seen "John" in the company of materialists dissolve into an impersonal force that the 
medium simply called: "questa forza;" [this force] while in intimate circles of spiritists, he took the form of dead people, more or less clumsily. Similarly, with controllers imbued with the idea of fraud ... the medium will remain under the influence of a suggestion of fraud. (Ochorowicz, 1896, p. 111)

\section{Théodore Flournoy}

Swiss psychologist Théodore Flournoy (18541920) (Figure 13) became well-known for his studies of mediumship and various psychological phenomena (see Alvarado et al., 2014; Claparède, 1921). In an early paper, "Genèse de Quelques Prétendus Messages Spirites," Flournoy (1899) explained cases of mediumship via the "medium's subconscious imagination, working on recollections or latent concerns" (Flournoy, 1899, p. 144). Flournoy concluded the paper stating that in healthy and

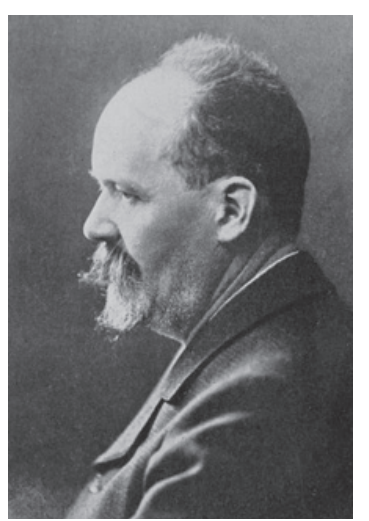

Figure 13. Théodore Flournoy normal persons the psychological state may be affected by mediumship, producing simulations of communications from spirits, being instead "the results of the subliminal operation of the ordinary faculties of the subject" (Flournoy, 1899, p. 158). The powers of this subconscious imagination, he wrote in a different paper, were able to "attain a degree of complexity and extension in no way different from the compositions and reflexions of the thinker and the novelist" (Flournoy, 1897, p. 419).

In the now classic study From India to the Planet Mars: A Study of a Case of Somnambulism, Flournoy (1900) focused on Hélène Smith (pseudonym for Catherine Élise Müller [1861-1929]), a medium who showed various automatisms and who became well-known about her communications involving planet Mars, including a Martian language, and previous lives in India and in France. ${ }^{21}$ Various communicators manifested through Smith, among them Victor Hugo, Marie Antoinette, and Leopold, who claimed to be Giuseppe Balsamo, the famous Cagliostro.

We are told that Smith had visions since childhood, and that she later experienced spontaneous episodes of daydreaming and reverie in 
which she saw images in her field of vision and heard voices. She also had impressions of solitude and of not belonging to her family. Her years of puberty showed a "wildness of ... dreams and automatisms, which were symptoms of a tendency to mental disintegration" (Flournoy, 1900, p. 33).

Smith showed trance, which could be partial (when she was in contact with a sitter, and with waking visons) or complete. During the latter she would awake "slowly through phases of deep sleep, alternating with relapses into somnambulistic gestures and attitudes, moments of catalepsy, etc. The final awakening is always preceded by several brief awakenings, followed by relapses into sleep" (p. 61).

Flournoy further wrote about her:

In her daily life she has only passing hallucinations limited to one or two of the senses, superficial hemisomnambulisms, compatible with a certain amount of self-possession ... ephemeral perturbations of no importance from a practical point of view ... In the séances, on the contrary, she presents the most grave functional alterations that one can imagine, and passes through accesses of lethargy, catalepsy, somnambulism, total change of personality ... (Flournoy, 1900, pp. 47-48).

As a medium she showed automatic writing and what Flournoy referred to as a "tendency of the subliminal imagination to reconstruct the deceased and to feign their presence" (p. 425). She also painted images that she perceived, some of which were related to Mars, and was susceptible to suggestions during the séances that could affect her waking experiences.

The spirit personalities and "romances" by the medium were considered to be produced via

the enormous suggestibility and auto-suggestibility of mediums, which render them so sensitive to all the influences of spiritistic reunions, and are so favorable to the play of those brilliant subliminal creations in which, occasionally, the doctrinal ideas of the surrounding environment are 


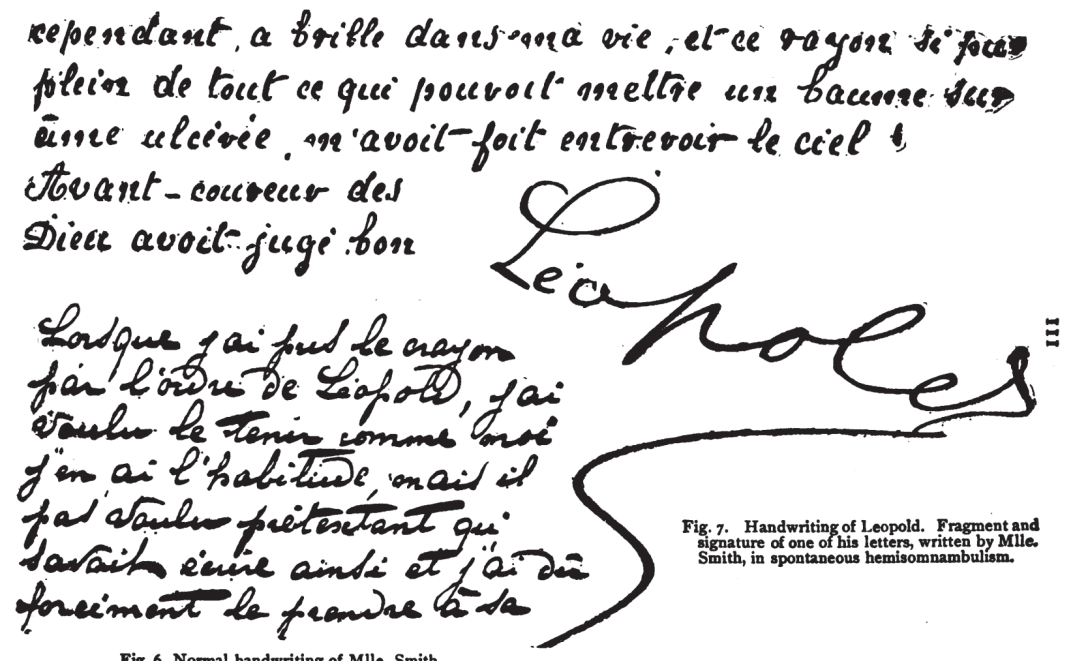

Figure 14. Writing of $\mathrm{H}$. Smith as Leopold (above) and her usual writing (below) (Flournoy, 1900, p. 111).

reflected together with the latent emotional tendencies of the medium herself. (Flournoy, 1900, p. 443)

One of the communicators, Leopold, was seen by the medium, but also wrote automatically, producing different calligraphy than the medium (Figure 14), a phenomenon recorded from the early days of Spiritualism (e.g., Edmonds \& Dexter, 1853, Appendix A). Leopold's communications, considered by Flournoy to originate from "that deep and delicate sphere in which we so often encounter the roots of hypnoid phenomena" (Flournoy, 1900, p. 91), were seen as a function of the interaction between the spiritistic context of the séance and the medium's suggestibility. This communicator "spoke with a deep bass voice, and a strong, easily recognizable Italian accent" (p. 104). The medium, Flournoy said, sometimes looked different when Leopold came through. Her "eyelids drop; her expression changes; her throat swells into a sort of double chin, which gives her a likeness of some sort to the well-known figure of Cagliostro" (p. 104). ${ }^{22}$ 


\section{FINAL THOUGHTS}

\section{Overview}

It is my hope that the brief summaries presented here of the writings of Tascher, Baillarger, Taine, Richet, Myers, von Hartmann, James, Janet, Ochorowicz, Héricourt, Liébeault, Blocq, Binet, and Flournoy will inform modern readers about some important, and somewhat forgotten nineteenth century ideas on the subject. To a great extent discussions of nineteenth century mediumship in terms of dissociation, and the unconscious regions of the mind, were part of a common trend to reduce unusual phenomena to known concepts of medicine and psychology (Gonçalves \& Ortega, 2013), a strategy seen frequently with mediumship (Le Maléfan, 1999). But there were different degrees of reductionism. Some, more consistent with the scientific establishment, only included dissociation (with manifestations such as changes of personality and state-specific memory), while others combined both dissociation and the supernormal. 23

While some of the authors of these writings emphasized the potential of the unconscious mind (Myers, Flournoy), others, as seen in the writings of Baillarger, von Hartmann, Janet, Blocq, and Binet, wrote in the context of pathology, something common in the writings of many French physicians and other nineteenth century students of mediumship (see Note 5).

Certainly, sampling biases may account for the association with pathology. If physicians looked for mediums among mental patients it is not surprising that many of them showed some degree of psychopathology. In addition, one wonders if physicians such as Janet actually saw enough mediums to make proper generalizations. But the idea did not escape criticism at the time.

The pathology of mediumship, an idea that seems to be less prevalent now, was combated by many (e.g., Crowell, 1877; Delanne, 1897b). ${ }^{24}$ An example is Myers' critique of Pierre Janet, consisting of the point that Janet's observations were limited to hysterics and other medical patients, which biased his ideas (Myers, 1889, p. 188; see also Maxwell, 1905/1903, p. 261). Furthermore, Gabriel Delanne (1857-1926), an engineer and leading French spiritist, was also critical of Janet and ideas of pathology. In his Le Phénomène Spirite Delanne (1897b) stated 
he had never seen hysterical crises in mediums (p. 137), and that pathology did not explain veridical phenomena with mediums (p. 143). ${ }^{25}$ The latter point was also made by Italian student of psychic phenomena Ernesto Bozzano (1862-1943), known for his strong defenses of discarnate agency. Bozzano (1899) also stated that "no theory of mental disaggregation or of subconscious automatism" could explain the evidence for supernormal knowledge found in the above-cited work of Richard Hodgson with Mrs. Piper (p. 364). In his view, ideas of subconscious activity and telepathy were too "elastic" and insufficient to explain mediumship without the inclusion of discarnate agency (see also the critiques published by other defenders of the spirit agency explanation such as Brofferio, 1892, pp. 323-324, and Noel, 1885). ${ }^{26}$

Myers was an example of a student of mediumship who not only discussed dissociative aspects of mediums' performances, but also believed there was evidence to accept that mediums produced veridical phenomena, such as information about sitters that could not be accounted for by conventional mechanisms. But he went beyond this. In his view the subliminal self-manifesting via dissociative means and other ways was the real self, and one that was not material, so it was the part that would survive bodily death (Myers, 1903, Vol. 1, p. 222; for similar views see du Prel, 1889/1884, and Geley, 1899). His ideas were controversial, not only for their emphasis on veridical cases, but because at the time many speculations about the unconscious emphasized pathological processes. Perhaps Myers would have furthered his position if instead of depending mainly on the work of others, he had conducted his own observations and experiments as did Gurney (1884) and Janet (1889).

There were others who accepted veridical mediumship (e.g., Hodgson, 1892; Lodge, 1890), as did James. His work represents an important early empirical attempt to study mediumship, and to relate it to dissociation and "supernormal" aspects of the medium's performance (Alvarado, 2016). But the majority of students of dissociation seemed to be skeptical about this possibility and ignored this aspect of the work of psychical researchers. In fact this prejudice, a problem with which psychical researchers still have to contend with today, led to the rejection of work that had the potential of enlarging conceptions of dissociation. Most of the time the veridical aspects of mediumship 
were just ignored or glossed over, or explained via suppositions that were not empirical, that expressed skepticism without showing actual mistakes. Such glossing over the issue was the case with both Binet and Janet, discussed above. Von Hartmann and Flournoy were exceptions, as was Richet. But both Richet and Flournoy wrote about veridical mediumship later, which brings us to twentieth century writings.

\section{Into the Twentieth Century}

The perspective of the joint action of dissociation and veridical information was further discussed by several later students of the subject (e.g., Flournoy, 1911; Kotik, 1908; Richet, 1922; Sudre, 1926). Flournoy (1911) stated the need to consider the combination of "mental transmission [telepathy] with the products to which memory and subconscious imagination of the sitters can give birth" (p. 213). All the evidential cases with Mrs. Piper, wrote German philosopher Traugott Konstantin Oesterreich (1880-1949), might be accounted for by the medium's creative imagination and telepathy working together (Oesterreich, 1923, pp. 44-45).

An important member of the Society for Psychical Research, Eleanor Sidgwick (1845-1936), who later became convinced of the possibility of communication with the dead, stated in her study "A Contribution to the Study of the Psychology of Mrs. Piper's Trance Phenomena":

I think it is probably a state of self-induced hypnosis in which her hypnotic self personates different characters either consciously and deliberately, or unconsciously and believing herself to be the person she represents, and sometimes probably in a state of consciousness intermediate between the two. In the trance state her normal powers transcend in some directions those of her ordinary waking self . . . And further ... she can obtain, imperfectly and for the most part fragmentarily, telepathic impressions. (E. Sidgwick, 1915, p. 330)

While such ideas are plausible if one accepts both dissociation (with its dynamics and need-serving capabilities), they are also speculative to a great degree. The analyses to support them are not always clear, 
and on many occasions they seem to depend on the preferences of the analyst, as compared with some clear evidence in the case, a problem shared with many psychodynamic analyses.

Nonetheless, these, and other issues, continued to be discussed during the twentieth century. Both Geley (1920/1919) and Myers (1903) disagreed with those who played down the importance of the unconscious mind and dissociation, arguing that mediumship and other phenomena showed the transcendental nature of the unconscious self, one that was not material and survived death. In Geley's words, when the higher faculties of the unconscious are released by the "decentralization" of limiting factors, we need to realize that they "are more completely accessible to us after the final rupture of those limitations by death" (Geley, 1919/1920, p. 262). ${ }^{27}$

Other relevant twentieth century discussions included the writings about specific mediums such as Mrs. Smead (Hyslop, 1906a), Helene Preiswerk (1881-1911) (Jung, 1975/1902), Hélène Smith (Flournoy, 1901), Eusapia Palladino (Morselli, 1908), and Leonora E. Piper (Tanner, 1910). The personalities manifested by Preiswerk, wrote psychologist Carl G. Jung (1875-1961), "are nothing but dramatized split-offs from her dream-ego" (Jung, 1975/1902, p. 78). Similarly, Ochorowicz referred to one of Stanislawa Tomczyck's controls as an "unconscious creation" that communicated via the "complementary unconscious imagination of the medium" (Ochorowicz, 1910, p. 130).

The concept of dissociation was present in discussions of pathology (e.g., Ballet, 1911; Janet, 1909; Lévy-Valensi, 1910), including French physician Joseph Grasset's (1849-1918) complex model of automatisms involving multiple unconscious processing centers (Grasset, 1908). ${ }^{28}$ Automatic writing, wrote a physician from a psychiatric hospital, was a form of psychological doubling in mediums developed due to emotional shocks, similar to those observed in the insane (Viollet, 1908, p. 25).

There were also later discussions of personation that assumed the workings of the unconscious imagination of mediums (Flournoy, 1911; Lebiedzinski, 1924; Maxwell, 1905/1903). This included French writer and psychical researcher's René Sudre's (1880-1968) essays about different aspects of the phenomenon, Personnages d'Au-Dela (Sudre, 1946), where he discussed pathological personation, such as that seen in hysteria, in mediumship, and in other contexts. In his view, the workings of the 
subliminal imagination produced personalities in both pathology and mediumship. But in mediumship, "thanks to the metapsychic faculties of the medium, they are satisfactory copies of an original that lived in the real scene of the world" (p. 59). ${ }^{29}$

Writing in his well-known Traité de Métapsychique, Richet (1922, pp. 55-62) devoted space in the book to argue for the existence of the unconscious capabilities of mediums to create characters and stories surrounding them (see also Alvarado, 2019a, Chapter 6). In his view: "The talents of the unconscious have more variety than the talents of the conscious" (Richet, 1922, p. 50). Echoing others such as Flournoy (1900, 1911), Richet argued that such talents were a combination of the workings of the unconscious mind of the medium and its memories, which were never forgotten, a phenomenon he called "pantomnesia" (Richet, 1922, p. 59).

There were also some discussions of the different gradations of mediumistic trance and of apparent different states of consciousness (Morselli, 1908, Vol. 1, pp. 258, 272-273; E. Sidgwick, 1915, Chapters 6-7). It was argued by some that medium Eusapia Palladino showed phenomena of higher magnitude in deeper stages of trance (Lombroso, 1909, pp. 104-105; Visani Scozzi, 1901, pp. 392-393). However, Morselli (Vol. 1, p. 209) disagreed, arguing that the medium showed no "absolute correspondence with the depth or phase of her trance states."

The idea that unconscious memories could account for some of the productions of mental mediums was accepted by some (e.g., Hyslop, 1906a, p. 215). This was also the case of American neurologist Morton Prince (1854-1929), who postulated that when the mind is in states lacking balance it may exteriorize unconscious memories. "Such phenomena," including mediumship and automatisms, "may then be interpreted as the flowering of functioning of the unconscious" (Prince, 1914, p. 260). ${ }^{30}$

But mention must also be made of those who argued for discarnate influence as compared with secondary personalities (e.g., Bozzano, 1923; Thomas, 1922). This included, among many, Myers' statement regarding Mrs. Thompson about his belief that most of her communications "are uttered through Mrs. Thompson's organism by spirits who for the time inform or 'possess' that organism" (Myers, 1902, p. 73). 
To conclude, perhaps the last word should be left to American philosopher and psychical researcher James H. Hyslop (1854-1920), who, while a strong believer in the supernormal and in survival of death, also saw that some cases could be explained by dissociation and other workings of the unconscious mind. He wrote:

The skeptic has apparently still to learn that the phenomena of secondary personality, while they indicate decided limitations to the supernormal, do not exclude the use of subliminal conditions for the transmission of it; and the ready believer in spirits has still to learn that these agencies are not so frequently active as he imagines. (Hyslop, 1906b, p. 297)

\section{CONCLUDING REMARKS}

We need to keep in mind that, in addition to dissociation, and the general workings of the unconscious mind, there are probably several other factors influencing mediumship, among them the health of mediums, the effects of practice, and the psycho-social environment in which séances are conducted. Writing about physical mediums, German physician and psychical researcher Albert F. von SchrenckNotzing (1862-1929) mentioned the suggestive influences of sitters and experimenters, and, on the side of the mediums, their spiritualistic ideas and training, and unknown physical dispositions (SchrenckNotzing, 1920, pp. 182-183). Certainly these, and other ideas, need to be considered in the context of the discussion presented above.

In the meantime, we would do well to remember that the ideas presented in this article belong to the various attempts-be they from psychical research, psychiatry, psychology, or Spiritualism-to explore the human mind empirically. For psychological science, ideas about mediumship were one more strand supporting the development of concepts about secondary mental states, what William James (1890a) referred to as the "hidden self." 


\section{NOTES}

1 For some discussions about the historical interrelationships between mediumship and dissociation see my previous papers (e.g., Alvarado, 2010, 2014) and the work of Crabtree (1993) and Le Maléfan (1999).

2 On this, and other relevant phenomena, see Friedman (2014) and Taves (1999). Many of these cases were referred to as trance, a term that has had different meanings and that remains to this day a vague and unprecise expression. In addition to its use to refer to alterations of consciousness in the literatures of mesmerism, hypnosis, and Spiritualism, during the last century the term was applied to automatic actions of habitual alcohol drinkers, lethargy, catalepsy, and deathlike states with near-death experiences elements. Interestingly, and reflecting various theoretical emphases, the terms dream, sleep, and somnambulism were used during the nineteenth century to cover a variety of visionary and dissociative phenomena (T. James, 1995, pp. 7-8).

3 Magnetic somnambulists were also credited with producing discourses about such things as God, evil, and religion (e.g., Olivier, 1854), and about other planets and celestial bodies (e.g., Peabody, 1838, Chapters 9 and 11). Deleuze (1813, Vol. 1, pp. 181-182) refers to somnambulistic dissertations about metaphysical and medical topics, and about a case he saw of a six-year-old girl who talked about and answered questions about several diseases.

4 Azam (1892), Binet (1892/1896), Elliotson (1846), and Myers (1888) presented discussions of cases of secondary personalities during the nineteenth century, as did Guinon (1891-1892) in his discussion of published cases and cases studied at the Salpêtrière. See also the work of Crabtree (1993), Hacking (1995), Kenny (1986), and Taylor and Martin's (1944) review of cases.

5 One theorist stated: "It is undeniable that the tendency of mediumship is to unhinge the mind, to destroy the mental balance, and often to produce the worst forms of insanity" (Hudson, 1893, p. 329). For overviews of pathological ideas about mediumship, see Alvarado (2018a), Alvarado and Zingrone (2012), and Le Maléfan (1999).

6 For overviews of the Piper case, see Gauld (1982, Chapter 3) and Tymn (2013). She became one of those paradigmatic cases that, in addition 
to her role as a producer of evidence for survival of death, and for the workings of dissociation, provided a focus that assisted in the development of methodological and conceptual issues in psychical research, and views about the workings of mental mediumship. Regarding dissociation, her case presented much information about the complexity of various shades and stages of trance (e.g., Hodgson, 1898, pp. 397-399; see also the detailed overview by E. Sidgwick, 1915). 7 On personation see Maxwell (1903/1905, pp. 64-71), Myers (1903, Vol. 2, Chapter 9), and Sudre (1926, 1946).

8 Unconscious cerebration referred to non-conscious production of ideas and actions via automatic brain processes (Carpenter, 1874, Chapter 13). On early nineteenth-century discussions of table turning, and its explanation by the idea of unconscious muscular movements, see Alvarado (2018b).

9 On Myers' ideas see Kelly (2007). Myers was influential in terms of ideas about unconscious action, but his defense of the supernormal was not well-received by many outside psychical research circles. Writing about automatists, he stated that some authors who cited him ignored his evidence for veridical information (Myers, 1892, p. 420).

10 Several writers in the early spiritualist literature argued for the influence of the medium's mental content on mediumistic communications (e.g., Ballou, 1852, p. 67; Brittan, 1852; Davis, 1853, p. 203; Edmonds \& Dexter, 1855, pp. 39-41). There are also discussions about problems from the side of the presumed spirit communicators (see the later writings of Hyslop, e.g., 1901b, 1914).

${ }^{11}$ The spiritualistic and psychical research literatures have many examples of discussions of these forces, presumed to come from the human body, as the agent behind mediumistic phenomena, such as movement of objects and materializations (for reviews, see Alvarado, 2006, and Alvarado \& Nahm, 2011).

${ }_{12}$ James wrote about this: "But the odd thing is that persons unexposed to spiritualist traditions will so often act in the same way when they become entranced ... I have no theory to publish of these cases, several of which I have personally seen" (W. James, 1890a, Vol. 1, p. 394).

${ }^{13}$ This interest in case studies is evident in W. James' lectures about 
exceptional mental states (E. Taylor, 1983) and in several of his publications (W. James, 1886, 1889, 1909). The importance of research "subjects" and clinical patients in the development of psychology and psychical research has been discussed elsewhere (e.g., Alvarado, 1993; Carroy, 1991; Hustvedt, 2011).

${ }^{14}$ Another investigator of Piper reported he was not successful in making Piper perform acts with post-hypnotic suggestion, nor to obtain "some manifestation of Phinuit by gesture, speech, or automatic writing, in reply to our inquiries and commands, and during the trance state some manifestation of Mrs. Piper" (Hodgson, 1892, p. 56).

${ }^{15}$ Janet cited many of Myers' observations in his discussion of mediumship (Janet, 1889, pp. 78, 121-122, 135-136, 371, 392-394, 403, 405, 415-419). He disagreed in several ways with Myers, but he credited him with presenting a theory involving "mental disintegration" in his articles about automatic writing, which Janet thought was more developed than previously published ideas (p. 403). Crabtree (2003) has compared the approaches of both men.

${ }^{16}$ Janet was citing Myers about a medium presenting choreic movements. What Myers (1885, p. 32) mentioned was "a stage of inco-ordinated movements, which might almost be taken for choreic," a comment referring to a case reported to him that involved writing in "an abruptly, jerking, and irregular way" (Myers, 1885, p. 27), not necessarily of choreic origin. Writing about Mrs. Piper, others have referred to jerking, twitching, and convulsive movements, sometimes taking place at the beginning of her trance (Hodgson, 1898, pp. 483, 587; Hyslop, 1901a, pp. 303, 304, 312; Leaf, 189o, pp. 618-619; Lodge, 189o, p. 444). According to Hodgson (1899, p. 55), these convulsions eventually stopped. A writer discussing mediumistic trance mentioned the "more or less tonic or clonic spasms" sometimes presented by mediums (Loveland, 1889, p. 49), while another stated that six cases of mediums showing convulsions he knew about were probably influenced by suggestion because they had seen other mediums doing the same (Anonymous, 1888, p. 285). Medium Eusapia Palladino said in 1902 that she was suffering from convulsions, which descriptions suggested Jacksonian epilepsy (Morselli, 1908, Vol. 1, p. 126). 
${ }^{17}$ James (1889, p. 549) found tactile anesthesia in two out of three automatic writers, as did others with various mediums (Magnin, 1903, p. 233; Newbold, 1898, p. 12; Morselli, 1908, Vol. 2, p. 14; Ochorowicz, 1896, p. 100). But Flournoy (1900, p. 42) did not. In the United States, physician William A. Hammond (1828-1900) claimed that mediums frequently experienced sensations of formication, numbness, prickling, and water on the skin, which he believed were an indication of nervous problems (Hammond, 1876, p. 118). Troubles of sensibility, such as loss of sensation in parts of the body, and hyperesthesia, were frequently discussed during the nineteenth century as symptoms of hysteria (e.g., Gilles de la Tourette, 1891, Vol. 1, Chapters 4-7).

${ }^{18}$ For information about Palladino's life and phenomena see the classic overviews of Carrington (1909) and de Rochas (1896, pp. 1-315), and more recent writings (e.g., Alvarado, 1993, 2011; Inglis, 1992, Chapters $35,38)$.

${ }_{19}$ There are many instances of (presumably unconscious) fraud throughout Palladino's career (e.g., Carrington, 1909, p. 182; Flammarion, 1907, pp. 520-521). For an early mention of possible unconscious fraud with the Fox sisters see Figuier (1860, pp. 334, 344).

${ }^{20}$ In this context ideoplasty referred to the use of psychic forces to fulfill an idea involving physical phenomena, a topic I have briefly discussed elsewhere (Alvarado, 2019c, pp. 79-80, see also Bozzano, 1926-1927; Hess, 2018). Ochorowicz speculated about collective agency to explain physical phenomena. This was the creation of a "separate dynamic body, at the expense of the sitters, including the medium" (Ochorowicz, 1896, p. 107), an idea similar to previous speculations about collective agency to account for physical phenomena (e.g., Anonymous, 1875; de Gasparin, 1854). The exteriorization of nerve force referred to was more clearly conceptualized later as a form of physical dissociation "between the organs [of the body] and the dynamic principle animating them, which can go as far as extraorganic manifestations, that is, outside the body" (Ochorowicz, 1909, p. 757). Similar versions of this idea were presented by others (Mackenzie, 1923, p. 200; Purdon, 1889, p. 1).

${ }^{21}$ Flournoy's (1900) account of the case became a classic of turn-ofthe-century ideas about the creative capabilities of the subconscious mind, attracting much attention in various circles (on the reception 
of the book, see Alvarado \& Zingrone, 2015). The book has been frequently discussed as an influential example of subliminal creative ability (e.g., Maraldi \& Alvarado, 2018). In addition, Flournoy's study "became a key addition to the other paradigm cases of mediumship and multiple personality that defined the era" (E. Taylor, 2009, p. 41).

${ }^{22}$ In a long paper Flournoy (1901) later continued discussing the case along the same lines. In addition, he discussed new communications about the Moon and Uranus, the dynamics of the Leopold communicator, and the influence of investigators on the unconscious productions of the medium. In later years the medium produced many paintings focusing on religious topics (Deonna, 1932; Lemaitre, 1908).

${ }^{23}$ It has been argued that inhibition (or dissociation?) of interfering material such as the content of the medium's mind and irrelevant spirit communications, could facilitate spirit action. Hodgson (1898, p. 401) referred to the need to avoid or to lessen confusions coming from various spirit communicators and from the medium's mind (see also Hyslop, 1910, p. 379; Hyslop, 1918, pp. 226, 231). This last author also argued, rather unclearly, that dissociation may be essential to real spirit mediumship, even in non-veridical cases (Hyslop, 1919, p. 403).

${ }^{24}$ There were also more complex views involving the coexistence of both pathology and supernormal phenomena (e.g., Lombroso, 1909; Lum, 1873; Morselli, 1908). See also Alvarado (2019b) and Alvarado and Biondi (2017).

${ }^{25}$ Interestingly, Delanne (1897a), like other spiritists, defended the existence of the perispirit, a fluidic body surrounding the spirit that was believed to provide a bridge between the spirit and the physical body involved with sensations, memories, and other processes. It was said that this principle explained unconscious memories and dissociation due to changes in the vibratory rate of the perispirit ( $p$. 226). Delanne's views were consistent with some ideas of mesmeric pathology (Alvarado, 2019b).

${ }^{26}$ For reviews of such critiques in the context of Flournoy and the Society for Psychical Research, see Alvarado and Zingrone (2015) and Cerullo (1982). Independently of this, the validity and usefulness of the concept of the unconscious mind was put in doubt for other reasons during 
the early twentieth century by some psychologists (e.g., Angell, 1909, p. 456; Titchener, 1915, pp. 327-328). Lack of interest in mediumship and dissociation by psychologists and psychiatrists was probably related to the lack of regard many had about the psychical researchers' emphasis in veridical mediumistic communications and the fact that there were many different concepts about the unconscious, most of which were not open to veridical manifestations (Münsterberg et al., 1910).

${ }^{27}$ Geley (1905) had already written about this in an earlier book in which he defended the existence of a subconscious mind with supernormal faculties. This self, he maintained, operated independently of the physical body, and preexisted and survived the physical body.

${ }^{28} \mathrm{He}$ proposed the existence of a superior psychism (our usual state of consciousness) and of an inferior psychism, made of a series of "polygons," or supposed centers in the nervous systems in charge of specific sensory and motor functions, generally automatic and unconscious. The polygons could coordinate the phenomena of mediumship (and other processes such as imagination, memory, and motor activity), during trance and during pathological states. Grasset also postulated that polygonal action did not involve veridical manifestations. In his view a medium was an individual with a facility to manifest polygonal action more than most persons. See also Grasset (1904, 1906).

${ }^{29}$ Another discussion of personation, and other mediumistic productions, came from the Italian psychiatrist Enrico Morselli (18521929), who discussed the topic in his book Psicologia e "Spiritismo" (Morselli, 1908, Vol. 2, pp. 63-67, 115-119). He argued that ideas in the unconscious minds of mediums, characterized by an infantile mentality, emerged when the medium was in the proper state. These ideas were organized by "the subconscious Imagination [which] ... arranges them in its own way, fertilizes and complicates them, and builds spirit romances"(Vol. 2, p. 468). Morselli was also keen to point out that phenomena took place when Palladino presumably was in her waking state, and that the medium "follows with her conscious attention all the developments of the phenomena . .." (Morselli, 1908, Vol. 1, p. 385).

30 Many other topics were considered during the early twentieth 
century, among them the concept of unconscious fraud (Hamilton et al., 1911), the similarity of spirit communicators to the phenomena reported in double and multiple personality cases (Troubridge, 1922), and analyses of automatic writing in terms of the authorship of the messages (anonymous and signed messages), the content of the messages (length, meaningless phrases), and language issues (meaningless words, poetic expressions) (Verrall, 1906).

\section{ACKNOWLEDGMENTS}

I am grateful to the Research Grants Committee of the Society for Psychical Research for funding the research that supported this paper.

\section{REFERENCES}

A., J. A. (1869). Remarkable case of somnambulism. Chicago Medical Journal, 26(20), 650-655.

Abercrombie, J. (1838). Inquiries concerning the intellectual powers and the investigation of truth (8th ed.). J. Murray.

Aksakof, A. (1895). Animisme et spiritisme [Animism and Spiritism] (B. Sandow, Trans.). P.-G. Leymarie [Original work published in German 1890]

Alvarado, C. S. (1993). Gifted subjects' contributions to psychical research: The case of Eusapia Palladino. Journal of the Society for Psychical Research, 59(833), 269-292.

Alvarado, C. S. (2002). Dissociation in Britain during the late nineteenth century: The Society for Psychical Research, 1882-1900. Journal of Trauma and Dissociation, 3(2), 9-33. https://doi.org/10.1300/j229vo3no2_02

Alvarado, C. S. (2006, July). Human radiations: Concepts of force in mesmerism, spiritualism and psychical research. Journal of the Society for Psychical Research, 70.3(884), 138-162.

Alvarado, C. S. (2009). Ambroise August Liébeault and psychic phenomena. American Journal of Clinical Hypnosis, 52(2), 111-121. https://doi.org/10.1080/00029157.2009.10401702

Alvarado, C. S. (2010, December). Classic text No. 84: 'Divisions of personality and spiritism' by Alfred Binet (1896). History of Psychiatry, 21(4), 487-500. https://doi.org/10.1177/0957154×10380513

Alvarado, C. S. (2011, March). Eusapia Palladino: An autobiographical essay. Journal of Scientific Exploration, 25(1), 77-101. https://www.scientificexploration.org/ docs/25/jse_25_1_Alvarado.pdf

Alvarado, C. S. (2014, January). Mediumship, psychical research, dissociation, and the powers of the subconscious mind. Journal of Parapsychology, 78(1), 98-114. 
Alvarado, C. S. (2016, March). Classic Text No. 105: 'Report of the Committee on Mediumistic Phenomena,' by William James (1886). History of Psychiatry, 27(1), 85-100. https://doi.org/10.1177/0957154X15623221

Alvarado, C. S. (2018a). Mediumship and pathology. In R. McLuhan (Ed.), Psi encyclopedia. https://psi-encyclopedia.spr.ac.uk/articles/mediumship-andpathology

Alvarado, C. S. (2018b, December). Table turning in the early 1850s: The séance reports of Agénor de Gasparin. Journal of Scientific Exploration, 32(4), 723-762.

Alvarado, C. S. (2019a). Charles Richet: A Nobel Prize winning scientist's explorations of psychic phenomena. White Crow Books.

Alvarado, C. S. (2019b, September). Classic text No. 119: Jules Bernard Luys on magnetic pathology. History of Psychiatry, 30(3), 359-374. https://doi. org/10.1177/0957154X19830955

Alvarado, C. S. (2019c, March). Musings on materializations: Eric J. Dingwall on "The Plasma Theory." Journal of Scientific Exploration, 33(1), 73-113. https://www.scientificexploration.org/docs/33/jse_33_1_Alvarado.pdf

Alvarado, C. S., \& Biondi, M. (2017, June). Classic Text No. 110: Cesare Lombroso on mediumship and pathology. History of Psychiatry, 28(2), 225-241. https://doi.org/10.1177/0957154X16686904

Alvarado, C. S., Maraldi, E. O., Machado, F. R., \& Zangari, W. (2014, July). Théodore Flournoy's contributions to psychical research. Journal of the Society for Psychical Research, 78.3(916), 149-168.

Alvarado, C. S., \& Nahm, M. (2011, April). Psychic phenomena and the vital force: Hereward Carrington on "Vital energy and psychical phenomena." Journal of the Society for Psychical Research, 75.2(903), 91-103.

Alvarado, C. S., \& Zingrone, N. L. (2012, July). Classic Text No. 90: 'The Pathology and Treatment of Mediomania', by Frederic Rowland Marvin (1874). History of Psychiatry, 23(2), 229-244. https://doi.org/10.1177/0957154X10396769

Alvarado, C. S., \& Zingrone, N. L. (2015, July). Note on the reception of Théodore Flournoy's study of Des Indes à la Planète Mars. Journal of the Society for Psychical Research, 79.3(920), 156-164.

Angell, J. R. (1909). Psychology: An introductory study of the structure and function of human consciousness (4th rev. ed.). Henry Holt.

Anonymous. (1854, April 22). Spirit personations-Death scenes. In The Spiritual Telegraph (Vol. III: Telepgraph Papers), 201-206. Partridge \& Brittan.

Anonymous. (1875, March 19). Speculations relating to new facts in spiritualism. Spiritualist Newspaper. http://iapsop.com/archive/materials/spiritualist/ spiritualist_v6_n12_mar_19_1875.pdf

Anonymous. (1888, November 16). The connection of hypnotism with the subjective phenomena of spiritualism. Proceedings of the Society for Psychical Research, 5(13), 279-287. http://iapsop.com/archive/materials/spr_proceedings/spr_ proceedings_v5_16_november_1888.pdf 
Anonymous. (1914). Le Docteur Jules Héricourt-Notice biographique [Doctor Jules Héricourt-A biographical note]. Science et Vie, 4(11), 277.

Azam, [E. E.]. (1887). Hypnotisme, double conscience et altérations de la personnalité: Le cas Felida $X$ [Hypnotism, double consciousness and alterations of personality]. J.-B. Baillière et fils.

Azam, E. (1892). Double consciousness. In D. H. Tuke (Ed.), A dictionary of psychological medicine (Vol. 1, pp. 401-406). J. \& A. Churchill.

Baillarger, J. (1861). [Untitled communication to the Société Médico-Psychologique]. Annales Médico-Psychologiques, 7(3), 92-93.

Ballet, G. (1911). La psychose hallucinatoire chronique et la désagrégation de la personnalité [Chronic hallucinatory psychosis and the disaggregation of personality]. L'encéphale, 8(6), 501-508.

Ballou, A. (1852). An exposition of views respecting the principal facts, causes, and peculiarities involved in spirit manifestations. Bela Marsh.

Barkworth, T. (1891-1892). Some recent experiments in automatic writing. Proceedings of the Society for Psychical Research, 7(18), 23-29.

Baxter, R. (1833). Narrative of facts, characterizing the supernatural manifestations in members of Mr. Irwin's congregation and other individuals, in England and Scotland, and formerly in the writer himself. James Nisbet.

Beard, G. M. (1879, July). The psychology of spiritualism. North American Review, $129,65-81$.

Beaunis, H. (1885, July). L'expérimentation en psychologie par le somnambulisme provoqué [Experimentation in psychology by induced somnambulism]. Revue Philosophique de la France et de l'Étranger, 20, 1-36, 113-134. https://www.jstor.com/stable/41074536

Belden, L. W. (1834). An account of Jane C. Rider, the Springfield somnambulist: The substance of which was delivered as a lecture before the Springfield Lyceum, Jan. 22, 1834. G. and C. Merriam.

Bertrand, A. (1823). Traité du somnambulisme et des differentes modifications qu'il présente [Treatise on somnambulism and the different modifications it presents]. J. G. Dentu.

Binet, A. (1889, February). Recherches sur les altérations de la conscience chez les hystériques [Investigations about the alterations of consciousness of movements in hysterics]. Revue Philosophique de la France et de l'Étranger, 27, 135-170. https://www.jstor.com/stable/41075010

Binet, A. (1890). On double consciousness: Experimental psychological studies. Open Court.

Binet, A. (1891, February 15). Les altérations de la personnalité d'après les travaux récens [Alterations of personality according to recent works]. Revue des deux Mondes, 103, 839-855. https://www.jstor.com/stable/44760932

Binet, A. (1896). Alterations of personality. D. Appleton. [Original published in French 1892] 
Binet, A., \& Féré, C. (1887). Recherches expérimentales sur la physiologie des mouvements chez les hystériques [Experimental researches into the physiology of hysterics]. Archives de Physiologie Normale et Pathologique, 9(s. 3), 320-373.

Biondi, M. (1988). Tavoli e medium: Storia dello Spiritismo in Italia [Tables and mediums: History of Spiritism in Italy]. Gremese.

Blocq, P. (1889). L'écriture médianimique [Mediumistic writing]. Bulletin Médical, 3, $1435-1437$.

Bourneville, [D. M.] (Ed.). (1886). Oeuvres complètes de ]. M. Charcot [Complete works of J. M. Charcot] (Vol. 1). Bureaux du Progrès Médical.

Bourru, H., \& Burot, P. (1888). Variations de la personnalité[Variations of personality]. J.-B. Baillière.

Bozzano, E. (1899). Spiritualismo e critica scientifica [Spiritualism and scientific criticism]. Rivista di Studi Psichici, 5(11-12), 356-379.

Bozzano, E. (1923, May 31-June 30). La storia di "Stasia" [The history of "Stasia"]. Luce e Ombra, 23(5-6), 171-179. http://iapsop.com/archive/materials/luce_e_ ombra/luce_e_ombra_v23_1923.pdf

Bozzano, E. (November 1926-July 1927). Pensiero e volontà: Forze plasticizzante e organizzanti [Thought and will: Plasticizing and organizing forces]. Luce e Ombra, 26(11), 481-488; 26(12), 556-563; 27(1), 34-44; 27(2-3), 60-69, 27(4), $164-175 ; 27(5), 223-230 ; 27(6) 250-262$.

Braid, J. (1853). Hypnotic therapeutics, ilustrated by cases: With an appendix on tablemoving and spirit-rapping. Murray and James

Brittan, S. B. (1852). Cerebral influence on revelation. The Shekinah, 2, 39-43. http:// iapsop.com/archive/materials/shekinah/shekinah_v2.pdf

Brittan, S. B., \& Richmond, B. W. (1853). A discussion of the facts and philosophy of ancient and modern spiritualism. Partridge \& Brittan.

Brofferio, A. (1892). Per lo Spiritismo [About Spiritism]. Domenico Briola.

Cahagnet, L.A. (1848-1854). Magnetisme [Magnetism] (3 vols.). Author (Vol. 1) and Germer Baillière (Vols. 2 and 3).

[Carpenter, W. B.]. (1853). Electrobiology and mesmerism. Quarterly Review, 93(186), 501-557.

Carpenter, W. B. (1874). Principles of mental physiology. D. Appleton.

Carrer, L. (Comp. \& Transl.) (2002). Ambroise-August Liébeault: The hypnological legacy of a secular saint. Virtualbookworm.com

Carrington, H. (1909). Eusapia Palladino and her phenomena. B. W. Dodge.

Carroy, J. (1991). Hypnose, suggestion et psychologie: L'invention de sujets [Hypnosis, suggestion and psychology: The invention of subjects]. Presses Universitaires de France. https://doi.org/10.3917/puf.carro.1991.01

Carroy, J., \& Plas, R. (1996, February). The origins of French experimental psychology: Experiment and experimentalism. History of the Human Sciences, 9(1), 73-84.

Carus, C. G. (1857). Über Lebensmagnetismus und über die magischen Wirkungen überhaupt [About the magnetism of life and magical effects]. F. A. Brockhaus. 
Casaubon, M. (1655). A treatise concerning enthusiasme. Printed by R. D.

Cerullo, J. J. (1982). The secularization of the soul: Psychical research in modern Britain. Institute for the Study of Human Issues.

Chambard, E. (1879, April). Sur un cas d'hystérie avec somnambulisme [On a case of hysteria with somnambulism]. Revue Mensuelle de Médecine et de Chrirugie, 3, 273-288.

Charpignon, J. (1848). Physiologie, médecine et métaphysique du magnétisme [Physiology, medicine and metaphysics of magnetism]. Germer Baillière.

Claparède, E. (1921). Théodore Flournoy: Sa vie et son oeuvre [Théodore Flournoy: His life and work]. Archives de Psychologie, 18(69-70), 1-125.

Cox, R. S. (2003). Body and soul: A sympathetic history of American Spiritualism. University of Virginia Press.

Crabtree, A. (1993). From Mesmer to Freud: Magnetic sleep and the roots of psychological healing. Yale University Press.

Crabtree, A. (2003). "Automatism" and the emergence of dynamic psychiatry. Journal of History of the Behavioral Sciences, 39(1), 51-70. https://doi. org/10.1002/jhbs.10089

Cridge, A. (1854). Epitome of spirit-intercourse. Bela Marsh.

Crowell, E. (1877). Spiritualism and insanity. Colby \& Rich.

D., M. (1867, March). Guardians of strength. Spiritual Magazine, 2(n.s.), 112-118. http://iapsop.com/archive/materials/spiritual_magazine_uk/spiritual_ magazine_s2_v2_n3_mar_1867.pdf

Dailey, A. H. (1894). Mollie Fancher, the Brooklyn enigma. Eagle Book Printing.

Davis, A. J. (1847). The principles of nature, her divine revelations, and a voice to mankind (3rd ed.). S. S. Lyon and Wm. Fishbough.

Davis, A. J. (1853). The present age and inner life: A sequel to spiritual intercourse: Modern mysteries classified and explained. Partridge and Brittan.

de Gasparin, Cte A. (1854). Des tables tournantes [Turning tables] (2 vol.). E. Dentu.

Delanne, G. (1897a). L'evolution animique: Essais de psychologie suivant le spiritisme [Soul evolution: Psychology according to Spiritism]. Chamuel.

Delanne, G. (1897b). Le phénomène spirite: Témoignages des savants [Spiritist phenomena: The testimony of scholars] (5th ed.). Chamuel.

Deleuze, J. P. F. (1813). Histoire critique du magnétisme animal [Critical history of animal magnetism] (Vol. 1). Mame.

Deleuze, J. P. F. (1825). Instruction pratique sur le magnétisme animal [Practical instruction about animal magnetism]. J.-G. Dentu.

De Morgan, S. E. [originally published with the pseudonym CD] (1863). From matter to spirit. Longman, Green, Longman, Roberts, \& Green.

Deonna, W. (1932). De la planète Mars en Terre Sainte: Art et subconscient [On planet Mars in Holy Land. E. de Boccard.

de Rochas, A. (1896). L'extériorisation de la motricité[The exteriorization of motricity]. Chamuel. 
Despine, A. (1840). De l'emploi du magnétisme animal et des eaux minérales dans le traitement des maladies nerveuses [On the use of animal magnetism and mineral waters in the treatment of nervous diseases]. Germer Baillière.

Dessoir, M. (1890). Das Doppel-Ich [The double self]. Ernest Günther.

Dewar, H. (1823). Report on a communication from Dr. Dyce of Aberdeen, to the Royal Society of Edinburgh, "On uterine irritation and its effects on the female constitution." Transactions of the Royal Society of Edinburgh, 9(2), 365-379. [Republished by Cambridge University Press 2013: https://doi. org/10.1017/s0080456800030969 ]

Du Prel, C. (1889). The philosophy of mysticism (2 vols.). George Redway. [Original work published in German 1884]

Du Prel, C. (1907). La magie: Science naturelle [Magic: A natural science] (Vol. 1). H. Vaillant-Carmanne. [Original work published published in German 1899]

Edelman, N. (1995). Voyantes, guérisseuses et visionnaires en France 1785-1914 [Seers, healers and visionaries in France, 1785-1914]. Albin Michel.

Edmonds, Judge [J. W.]. (1860). Letters to the "New York Tribune," on Spiritualism [Spiritual Tracts, No. 10). No publisher.

Edmonds, Judge (J. W.]. (n.d., ca 1875). Letters and tracts on Spiritualism (J. Burns, Ed.). J. Burns. http://iapsop.com/ssoc/1875_edmonds_tappan__letters_ and_tracts_on_spiritualism.pdf

Edmonds, J. W., \& Dexter, G. T. (1853). Spiritualism. Partridge \& Brittan.

Edmonds, J. W., \& Dexter, G. T. (1855). Spiritualism. Partridge \& Brittan.

Ellenberger, H. F. (1970). The discovery of the unconscious: The history and evolution of dynamic psychiatry. Basic Books.

Elliotson, J. (1843). Numerous cases of surgical operation without pain in the mesmeric state. $\mathrm{H}$. Baillière.

Elliotson, J. (1846, July). Instances of double states of consciousness independent of mesmerism. Zoist, 4(14), 157-187. http://iapsop.com/archive/materials/ zoist/zoist_v4_n14_july_1846.pdf

Ermacora, G. B. (1894, February). Attività subcosciente e spiritismo [Subconscious activity and spiritism]. Lux: Bolletino dell'Accademia Internazionale per gli studi psicologici, 6(2), 37-48. http://iapsop.com/archive/materials/lux_rome/lux_v6_1893.pdf

Esdaile, J. (1847). Mesmerism in India, and its practical application in surgery and medicine. Silas Andrus and Son.

Evrard, R., Pratte, E. A., \& Cardeña, E. (2018). Pierre Janet and the enchanted boundary of psychical research. History of Psychology, 21(2), 100-125. https://doi.org/10.1037/hopoo00086

Faraday, M. (1853, July 2). Professor Faraday on table-moving. The Athenaeum: Journal of Literature, Science, and the Fine Arts, No. 1340, 801-803.

Figuier, L. (1860). Histoire du merveilleux dans les temps modernes [History of the marvellous during modern times] (Vol. 4). Hachette.

Flammarion, C. (1907). Mysterious psychic forces. Small, Maynard. 
Flournoy, T. (1897). Quelques faits d'imagination subliminale chez les médiums [Some facts of subliminal imagination in mediums]. In Dritter Internationaler Congress für Psychologie in München vom 4. bis 7. August, 1896. (pp. 419-420). J. F. Lehmann.

Flournoy, T. (1899, February). Genèse de quelques prétendus messages spirites [Genesis of some supposed spirit messages]. Revue Philosophique de la France et de l'Étranger, 47, 144-158.

Flournoy, T. (1900). From India to the Planet Mars: A study of a case of somnambulism with glossolalia. Harper \& Brothers. https://doi.org/10.1037/10911-000

Flournoy, T.(1901, December). Nouvelles observations sur un cas de somnambulisme avec glossolalie [New observations of a case of somnambulism with glossolalia]. Archives de Psychologie, 1(2), 101-255. https://archive.org/details/ nouvellesobservooflou/page/n3/mode/2up

Flournoy, T. (1911). Spiritism and psychology. Harper \& Brothers.

Foschi, R. (2003). L'indagine sulla personalità alle origini della psicologia scientifica francese (1870-1885) [The investigation of personality at the origins of French scientific psychology (1870-1885)]. Physis, 40(1-2), 63-105.

Friedman, K. A. K. (2014). Soul sleepers: A history of somnambulism in the United States, 1740-1840. Doctoral dissertation, Harvard University.

Garrett, C. (1987). Spirit possession and popular religion: From the Camisards to the Shakers. John Hopkins University Press.

Gauld, A. (1968). The founders of psychical research. Routledge and Kegan Paul.

Gauld, A. (1982). Mediumship and survival: A century of investigations. Heinemann.

Gauld, A. (1992). A history of hypnotism. Cambridge University Press.

Gauthier, A. (1842). Histoire du somnambulisme chez tous les peuples [History somnambulism in all people] (2 vols.). Félix Malteste.

Gauthier, A. (1845). Traité pratique du magnétisme et du somnambulisme [Practical treatise of magnetism and somnambulism]. Germer Baillière.

Geley, G. [under the pseudonym E. Gyel]. (1899). L'être subconscient [The subconscious being]. Félix Alcan.

Geley, G. (1905). L'être subconscient [The subconscious being] (2nd ed.). Félix Alcan.

Geley, G. (1920). From the unconscious to the conscious. Williams Collins Sons. [Original work published in French in 1919]

Gilles de la Tourette, [G.]. (1891). Traité clinique et thérapeutique de l'hystérie d'après l'enseignement de la Salpêtrière [Clinical and therapeutic treatise of hysteria according to the teachings of the Salpêtrière] (Vol. 1). E. Plon, Nourrit.

Gonçalves, V. P., \& Ortega, F. (2013, April/June). Uma nosologia para os fenômenos sobrenaturais e a construção do cérebro "possuído" no século XIX [A nosology for supernatural phenomena and the construction of the "possessed" brain during the XIXth century]. Historia, Ciências, Saude-Manguinhos, 20(2), 373390. https://doi.org/10.1590/So104-59702013005000004

Grasset, J. (1904). Le Spiritisme devant la science [Spiritism before science]. Coulet et Fils. 
Grasset, J. (1906). Le psychisme inferieur [The inferior psychism]. Chevalier et Rivière. Grasset, J. (1908). L'occultisme hier et aujourd'hui] (2nd ed.). Coulet et Fils.

Gregory, L. M. (1866, May). A seance with Mr. Home. Spiritual Magazine, I(n.s.), 226-227. http://iapsop.com/archive/materials/spiritual_magazine_uk/ spiritual_magazine_s2_v1_n5_may_1866.pdf

Gregory, W. (1851). Letters to a candid inquirer, on animal magnetism. Blanchard \& Lea. Gregory, W. (1856). Le spiritualisme en Angleterra [Spiritualism in England]. Journal du Magnétisme, 15(238), 309-334. http://iapsop.com/archive/materials/ journal_du_magnetisme/journal_du_magnetisme_v15_1856.pdf

Guinon, G. (1891-1892). Documents pour server à l'histoire des somnambulismes [Documents for the history of somnambulism]. Progrès Médical, 13(s. 2), (20), 401-404, (21), 425-429, (23) 460-466, (26), 513-517; 14(s. 2), (29), 41-49, (34) 137-141; 15(s. 2), (11), 193-196, (13), 236-238, (19), 361-364, (21), 401-402; 16(s. 2), (27), 1-4, (28), 17-21, (31), 73-76, (34), 131-134.

Gurney, E. (1884, January). The stages of hypnotism. Proceedings of the Society for Psychical Research, 2(5), 61-72. http://iapsop.com/archive/materials/spr_ proceedings/spr_proceedings_v2_18_january_1884.pdf

Gurney, E., \& Myers, F. W. H. (1885, May-June). Some higher aspects of mesmerism. Proceedings of the Society for Psychical Research, 3(9), 401-423. http://iapsop.com/archive/materials/spr_proceedings/spr_proceedings_ V3_may_june_1885.pdf

Hacking, I. (1995). Rewriting the soul: Multiple personality and the sciences of memory. Princeton University Press.

Haddock, J. W. (1851). Somnolism \& psycheism (2nd ed.). James S. Hodson.

Hamilton, W. H., Smyth, J. S., \& Hyslop, J. H. (1911). A case of hysteria. Proceedings of the American Society for Psychical Research, 5(10), 1-656. http://iapsop.com/ archive/materials/aspr_proceedings/aspr_proceedings_v5_1911.pdf

Hammond, W. A. (1876). Spiritualism and allied causes and conditions of nervous derangement. G. P. Putnam's Sons.

Hardinge, E. (1860). Six lectures on theology and nature. Hitt.

Héricourt, J. (1886, February). Un cas de somnambulisme à distance [A case of somnambulism at a distance]. Revue Philosophique de la France et de l'Étranger, 21, 200-203.

Héricourt, J. (1889). L'activité inconsciente de l'esprit [The unconscious activity of the mind]. Revue Scientifique, 44(9), 257-268.

Hess, K. M. (2018). The idea of ideoplasty and occult phenomena in the theoretical and empirical research of Julian Ochorowicz. Preternature, 7(2), 239-274. https://doi.org/10.5325/preternature.7.2.0239

Hill-Tout, C. H. (1895). Some psychical phenomena bearing upon the question of spirit control. Proceedings of the Society for Psychical Research, 11(28), 309-316. http:// iapsop.com/archive/materials/spr_proceedings/spr_proceedings_v11_1895.pdf

Hodgson, R. (1891). A case of double consciousness. Proceedings of the Society for 
Psychical Research, 7(19), 221-255. http://iapsop.com/archive/materials/spr_ proceedings/spr_proceedings_v7_1891-2.pdf

Hodgson, R. (1892). A record of observations of certain phenomena of trance. Proceedings of the Society for Psychical Research, 8(21), 1-167. http://iapsop. com/archive/materials/spr_proceedings/spr_proceedings_v8_1892.pdf

Hodgson, R. (1898). A further record of observations of certain phenomena of trance. Proceedings of the Society for Psychical Research, 13(33), 284-582. http://iapsop.com/archive/materials/spr_proceedings/spr_proceedings_ v13_1897-8.pdf

Hodgson, R. (1899, February 4). Miss Freer and Mrs. Piper. Light, 19(943), 55-56. http://iapsop.com/archive/materials/light/light_v19_feb_1899.pdf

Hudson, T. J. (1893). The law of psychic phenomena: A working hypothesis for the systematic study of hypnosis, spiritism, mental therapeutics, etc. A. C. McClurg.

Hustvedt, A. (2011). Medical muses: Hysteria in Nineteenth-Century Paris. W. W. Norton.

Hyslop, J. H. (1901a). A further record of observations of certain trance phenomena. Proceedings of the Society for Psychical Research, 16(41), 1-649. https://www. unz.com/print/Harpers-1901mar-00632/

Hyslop, J. H. (1901b, March). Nature of life after death. Harper's Monthly Magazine, 102(610), 632-639. https://www.unz.com/print/Harpers-1901mar-00632/

Hyslop, J. H. (1906a). Apparent subconscious fabrication. Journal of Abnormal Psychology, 1(5), 201-215. https://doi.org/10.1037/hoo74871

Hyslop, J. H. (1906b). Borderland of psychic research. Herbert B. Turner.

Hyslop, J. H.(1910). A record and discussion of mediumistic experiments. Proceedings of the American Society for Psychical Research, 4(1), 1-812. http://iapsop.com/ archive/materials/aspr_proceedings/aspr_proceedings_v4_1910.pdf

Hyslop, J. H. (1914). A hypothetical process of communication. Journal of the American Society for Psychical Research, 8(8), 377-389. http://iapsop.com/ archive/materials/aspr_proceedings/aspr_journal_v8_1914.pdf

Hyslop, J. H. (1918). Life after death: Problems of the future life and its nature. E. P. Dutton. Hyslop, J. H. (1919). Contact with the other world: The latest evidence as to communication with the dead.. Century.

Inglis, B. (1992). Natural and supernatural: A history of the paranormal from earliest times to 1914 (Rev. ed.). Prism.

James, T. (1995). Dream, creativity, and madness in nineteenth-century France. Oxford University Press.

https://doi.org/10.1093/acprof:0so/9780198151883.001.0001

James, W. (1886, July). Report of the Committee on Mediumistic Phenomena. Proceedings of the American Society for Psychical Research, 1(2), 102-106. http://iapsop.com/archive/materials/aspr_proceedings/aspr_proceedings_ V1_1885-1889.pdf

James, W. (1889, March). Notes on automatic writing. Proceedings of the American 
Society for Psychical Research, 1(4), 548-564. http://iapsop.com/archive/ materials/aspr_proceedings/aspr_proceedings_v1_1885-1889.pdf

James, W. (1890a, March). The hidden self. Scribner's Magazine, 7(3), 361-373. https:// babel.hathitrust.org/cgi/pt?id=umn.319510019199803\&view=1up\&seq=373

James, W. (189ob). The principles of psychology (Vol. 1). Henry Holt. https://doi.org/10.1037/10538-000

James, W. (189oc). A record of observations of certain phenomena of trance (5) Part III. Proceedings of the Society for Psychical Research, 6(17), 651-659. http://iapsop. com/archive/materials/spr_proceedings/spr_proceedings_v6_11_july_1890.pdf

James, W. (1909). Report on Mrs. Piper's Hodgson-control. Proceedings of the Society for Psychical Research, 23(58), 2-121.

Janet, P. (1886, December). Les actes inconscientes et la dédoublement de la personnalité pendant le somnambulisme provoqué [Unconscious acts and the doubling of personality during induced somnambulism]. Revue Philosophique de la France et de l'Étranger 22, 577-592.

Janet, P. (1887, May). L'anesthésie systématisée et la dissociation des phénomènes psychiques [Systematized anesthesia and the dissociation of psychic phenomena]. Revue Philosophique de la France et de l'Étranger, 23, 449-472.

Janet, P. (1889). L'automatisme psychologique [Psychological automatism. Félix Alcan.

Janet, P. (1892, April). Le spiritisme contemporain [Contemporary Spiritism]. Revue Philosophique de la France et de l'Étranger, 33, 413-442.

Janet, P. (1904). Névroses et idées fixes [Neuroses and fixed ideas] (2nd ed., Vol. 1). Félix Alcan.

Janet, P. (1909). Dèlire systématique à la suite de pratiques du spiritisme [Systematic delirium as a consequence of spiritist practices]. L'Éncephale, 4(4), 363-367.

Jung, C. G. (1975). On the psychology and pathology of so-called occult phenomena. In C. G. Jung, Psychiatric studies (The collected works of C. G. Jung, Vol. 1, pp. 3-8). Princeton University Press [First published in German 1902]

Kelly, E. W. (2007). F. W. H. Myers and the empirical study of the mind-body problem. In E. Kelly, E. W, Kelly, A. Crabtree, A. Gauld, M. Grosso, \& B. Greyson, Irreducible mind: Toward a psychology for the 21st century (pp. 47-115. Rowman \& Littlefield.

Kenny, M. G. (1986). The passion of Ansel Bourne: Multiple personality in American culture. Smithsonian Institution Press.

Kerner, J. A. C. (1845). The seeress of Prevorst. J. C. Moore. [Abridgement of Kerner's Die Seherin von Prevorst, 1829, C. Crowe (tr.)]

Knapp, K. D. (2017). William James: Psychical research and the challenge of modernity. University of North Carolina Press. https://doi.org/10.5149/northcarolina/9781469631240.001.0001

Kotik, N. G. (1908). Die Emanation der psychophysischen Energie. [The emanation of psychophysical energy]. J. F. Bergmann.

Lafontaine, C. (1860). L'art de magnétiser, ou le magnétisme animal considéré sous 
le point de vue théorique, pratique et thérapeutique [The art of magnetizing, or animal magnetism considered from the theoretical, practical and therapeutic point of view] (3rd ed.). Germer Baillière.

[Lang, W.]. (1843). Mesmerism. Fraser.

Lausanne [pseudonym of Sarrazine de Montferrier, A. A. V.]. (1816, July 1). Histoire du magnétisme animal [History of animal magnetism]. Annales du Magnétisme Animal, 2, 3-26.

Leaf, W. (1890). A record of observations of certain phenomena of trance (3). Part II. Proceedings of the Society for Psychical Research, 6(17), 558-646.

Lebiedzinski, P. (1924). L'ideoplastie comme hypothèse directrice des études métapsychiques [Ideoplasty as the directing hypothesis of metapsychic studies]. In L'Etat Actuel des Recherches Psychiques d'après les travaux du Ilme Congrès International tenu à Varsovie en 1923 en l'honneur du Dr Julien Ochorowicz (pp. 286-300). Presses Universitaires de France.

Lemaître, A. (1908, July). Un nouveau cycle somnambulique de Mlle Smith [A new somnambulic cycle of Mlle Smith]. Archives de Psychologie, 7, 63-83.

Le Maléfan, P. (1999). Folie et Spiritisme (1850-1950) [Madness and Spiritism]. L'Harmattan.

Lévy-Valensi, J. (1910). Spiritisme et folie [Spiritism and madness]. L'Encéphale, 5(6), 696-716.

Liébeault, A.-A. (1889). Le sommeil provoqué et les états analogues [Induced sleep and similar states]. Octave Doin.

Lodge, O. (1890). A record of observations of certain phenomena of trance (2). Part I. Proceedings of the Society for Psychical Research, 6(17), 443-557. http://iapsop. com/archive/materials/spr_proceedings/spr_proceedings_v6_11_july_189o.pdf

Lombardo, G. P., \& Foschi, R. (2003). The concept of personality in 19th-century French and 2oth-century American psychology. History of Psychology, 6(2), 123-142. https://doi.org/10.1037/1093-4510.6.2.123

Lombroso, C. (1909). After death-What?: Spiritistic phenomena and their interpretation. Small, Maynard. https://doi.org/10.1037/13627-000

London Dialectical Society. (1871). Report on Spiritualism. Longmans, Green, Reader \& Dyer. Loveland, J. S. (1889). Mediumship: A course of seven lectures. Moses Hull.

Lum, D. D. (1873). The "Spiritual" delusion. J. B. Lippincott.

Macario, M. M. A. (1857). Du sommeil des rêves et du somnambulisme dans l'état de santé et de maladie [Dreams during sleep and somnambulism during the states of health and disease]. Perisse Frèrs.

Mackenzie, W. (1923). Metapsichica moderna [Modern metapsyhics]. Librerie di Scienze e Lettere.

Magnin, E. (1903, April 1). Un bon médium à l'horizon [A good medium on the horizon]. Revue Spirite: Journal d'Études Psychologiques, 46(4), 232-235.

Mais, C. (1814). The surprising case of Rachel Baker, who prays and preaches in her sleep (2nd ed.). Whiting and Watson. 
Maraldi, E. de O., \& Alvarado, C. S. (2018). Classic Text No. 113: Final chapter, From India to the planet Mars: A study of a case of somnambulism with glossolalia by Théodore Flournoy (1900). History of Psychiatry, 29(1), 110-125. https://doi.org/10.1177/0957154×17734782

Maraldi, E. de O., Ribeiro, R. N., \& Krippner, S. (2019). Cultural and group differences in mediumship and dissociation: Exploring the varieties of mediumistic experiences. International Journal of Latin American Religions, 3(1), 170-192. https://doi.org/10.1007/s41603-019-00076-0

Martineau, H. (1845). Letters on mesmerism (2nd ed.). Edward Moxon.

Marvin, F. R. (1874). The philosophy of spiritualism and the pathology and treatment of mediomania: Two lectures. A. K. Butts.

Mason, R. O. (1893, September). Duplex personality. Journal of Nervous and Mental Disease, 18(9), 593-598. https://doi.org/10.1097/00005053-189309000-00001

Maxwell, J. (1905). Metapsychical phenomena: Methods and observations (trans. Laura I. Finch). Duckworth. [First published in French in 1903]

Mayo, T. (1847). Clinical facts and reflections: Also, remarks on the impunity of murder in some cases of presumed insanity. Longman, Brown, Green, and Longmans.

Mitchell, G. W. (1876). $X+Y=Z$ : or the sleeping preacher of North Alabama: Containing an account of most wonderful mysterious mental phenomena, fully authenticated by living witnesses. W. C. Smith.

Mitchill, S. L. (1817). A double consciousness, or a duality of person in the same individual. Medical Repository of Original Essays and Intelligence Relative to Physic, Surgery, Chemistry, and Natural History, 3(n.s., 2), 185-186.

Moore, J. S. (1870). A case of somnambulism. Medical Archives, 4(6), 331-332.

Moore, R. L. (1977). In search of white crows: Spiritualism, parapsychology, and American culture. Oxford University Press.

Morin, A.-S. (1860). Du magnétisme et des sciences occultes [On magnetism and occult sciences]. Germer Baillière.

Morselli, E. (1908). Psicologia e "Spiritismo:" Impressioni e note critiche sui fenomeni medianici di Eusapia Paladino [Psychology and "Spiritism:" Impressions and critical notes about the mediumistic phenomena of Eusapia Paladino] (2 vols.). Fratelli Bocca.

Moses, W. S. [under the pseudonym M. A. Oxon] (1879). Spirit identity. W. H. Harrison.

Münsterberg, H., Ribot, T. A., Janet, P., Jastrow, J., Hart, B., \& Prince, M. (1910). Subconscious phenomena. Richard G. Badger.

Myers, F. W. H. (1884). On a telepathic explanation of some so-called spiritualistic phenomena: Part I. Proceedings of the Society for Psychical Research, 2(7), 217-237.

Myers, F. W. H. (1885). Automatic writing.-II. Proceedings of the Society for Psychical Research, 3(8), 1-63. http://iapsop.com/archive/materials/spr_proceedings/ spr_proceedings_V4_29_october_1885.pdf

Myers, F. W. H. (1886). Human personality in the light of hypnotic suggestion. 
Proceedings of the Society for Psychical Research, 4(10), 1-24. http://iapsop.com/ archive/materials/spr_proceedings/spr_proceedings_v4_29_october_1885.pdf

Myers, F. W. H. (1888). French experiments on strata of personality. Proceedings of the Society for Psychical Research, 5(13), 374-397. http://iapsop.com/ archive/materials/spr_proceedings/spr_proceedings_v5_december_1888_ supplement.pdf

Myers, F.W. H.(1889). Professor Pierre Janet's 'Automatisme Psychologique.' Proceedings of the Society for Psychical Research, 6(15), 186-199. http://iapsop.com/archive/ materials/spr_proceedings/spr_proceedings_v6_july_1889_supplement.pdf

Myers, F. W. H. (1890). A record of observations of certain phenomena of trance (1) Introduction. Proceedings of the Society for Psychical Research, 6(17), 436-442. http://iapsop.com/archive/materials/spr_proceedings/spr_proceedings_ v6_11_july_1890.pdf

Myers, F. W. H. (1892). Review of Les Altérations de la Personnalité, by A Binet. Mind, I(13), 417-421.

Myers, F. W. H. (1902). On the trance-phenomena of Mrs. Thompson. Proceedings of the Society for Psychical Research, 17(44), 67-74. http://iapsop.com/archive/ materials/spr_proceedings/spr_proceedings_v17_1901-3.pdf

Myers, F. W. H. (1903). Human personality and its survival of bodily death (2 vols.). Longmans, Green.

Newbold, W. R. (1898). A further record of observations of certain phenomena of trance. Proceedings of the Society for Psychical Research, 14(34), 6-49. http://iapsop.com/ archive/materials/spr_proceedings/spr_proceedings_v14_1898-9.pdf

Nias, H. (1999). The artificial self: The psychology of Hippolyte Taine. Legenda.

Nicolas, S. (2002). Histoire de la psychologie française [History of French psychology]. Editions In Press.

Nicolas, S., \& Ferrand, L. (2002). Alfred Binet and higher education. History of Psychology, 5(3), 264-283. https://doi.org/10.1037/1093-4510.5.3.264

Noel, R. (1885, November 28 \& December 5). Spiritism versus other theories (being an answer to Messrs. von Hartmann, Myers, and Gurney). Light, 5(256), 587-588; (257), 599-600. http://iapsop.com/archive/materials/light/light_v5_nov_1885. pdf; http://iapsop.com/archive/materials/light/light_v5_dec_1885.pdf

Ochorowicz, J. (1887). De la suggestion mentale [On mental suggestion]. Octave Doin.

Ochorowicz, J. (1896). La question de la fraude dans les expériences avec Eusapia Paladino. Annales des Sciences Psychiques, 6(2), 79-123. http://iapsop.com/archive/materials/ annales_des_sciences_psychiques/annales_des_sciences_psychiques_v6_1896.pdf

Ochorowicz, J. (1909). Hypnotisme et mesmérisme. In C. Richet (Ed.), Dictionnaire de Physiologie (Vol. 8, pp. 709-778). Félix Alcan.

Ochorowicz, J. (1910). Les rayons rigides et les rayons $X^{x}$ [Rigid rays and $X^{x}$ rays]. Annales des Sciences Psychiques, 20(7-8), 97-105; (9-10), 129-136; (11-12), 172178; (13-14), 204-209; (15-16), 225-231; (17-18), 257-263; (19-20), 295-302; (2122), 336-344; (23-24), 357-370. http://iapsop.com/archive/materials/annales_ 
des_sciences_psychiques/annales_des_sciences_psychiques_v20_1910.pdf Oesterreich, T. K. (1923). Occultism and modern science [2nd German ed.]. McBride. Oesterreich, T. K. (1930). Possession: Demoniacal and other. Kegan Paul, Trench, Trubner. [Original work published in German 1921]

Olivier, J. (1854). Traité de magnétisme suivi des paroles d'un somnambule et d'un recueil de traitements magnétiques [Treatise on magnetism followed by the words of a somnambulist and a collection of magnetic treatments]. Germer Baillière.

Patrick, G. T. W. (1898, November). Some peculiarities of the second personality. Psychological Review, 5(6), 555-578. https://doi.org/10.1037/hoo 73460

Peabody, J. R. (1838). A world of wonders, or, divers developments, showing the triumph of animal magnetism in New England (3rd ed.). Robert S. Davis.

Perrier, A. (1854, February 10). Études et théories: Recherches médico-magnétiques. Journal du Magnétisme, 13(181), 65-80. http://iapsop.com/archive/materials/ journal_du_magnetisme/journal_du_magnetisme_v13_1854.pdf

Plas, R. (2000). Naissance d'une Science Humaine: La Psychologie [Birth of a human science: Psychology. Presses Universitaires de Rennes.

Podmore, F. (1902). Modern Spiritualism: A history and a criticism (2 vols.). Methuen.

Prichard, J. C. (1835). Somnambulism and animal magnetism. In J. Forbes, A. Tweedie, \& J. Conolly (Eds.), The cyclopaedia of practical medicine (Vol. 4, pp. 21-39). Sherwood, Gilbert, and Piper, and Baldwin and Cradock.

Prince, M. (1890, May 15). Some of the revelations of hypnotism: Post hypnotic suggestion, automatic writing, and double personality. Boston Medical and Surgical Journal, 122(20), 463-467; (21), 493-495. https://doi.org/10.1056/nejm189005151222001

Prince, M. (1914). The unconscious: The fundamentals of human personality, normal and abnormal. Macmillan.

Purdon, J. E. (1889, January 26). Animal magnetism, and the supplementary working hypothesis of scientific spiritualism. Religio-Philosophical Journal, $45(23), 1,8$.

Puységur, A. M. J., de C. (1784). Mémoires pour servir à l'histoire et à l'établissement du magnétisme animal [Memoires for the history and establishment of animal magnetism]. No publisher.

Raymond, F., \& Janet, P. (1908). Névroses et idées fixes [Neuroses and fixed ideas] (2nd ed., Vol. 2). Félix Alcan.

Ribot, T. (1885). Les maladies de la personnalité [The diseases of personality]. Félix Alcan.

Richet, C. (1883, March). La personnalité et la mémoire dans le somnambulisme [Personality and memory in somnambulism]. Revue Philosophique de la France et de l'Étranger, 15, 225-242. https://www.jstor.com/stable/41074407

Richet, C. (1884, December). La suggestion mentale et le calcul des probabilités [Mental suggestion and the calculation of probabilities]. Revue Philoso-phique de la France et de l'Étranger, 18, 609-674. https://www.jstor.com/stable/41072311 
Richet, C. (1886). Les mouvements inconscients [Unconscious movements]. In M. Berthelot (Ed.), Hommage à Monsieur Chevreul a l'occasion de son centenaire 31 Aôut 1886 (pp. 79-94). Félix Alcan.

Richet, C. (1889, July 8). Further experiments in hypnotic lucidity or clairvoyance. Proceedings of the Society for Psychical Research, 6(15), 66-83. http://iapsop. com/archive/materials/spr_proceedings/spr_proceedings_v6_8_july_1889.pdf

Richet, C. (1922). Traité de métapsychique [Treatise of metapsychics]. Félix Alcan. http://iapsop.com/ssoc/1922__richet_traite_de_metapsychique.pdf

Ritti, A. (1891). Mort de M. le Dr. Baillarger [Death of M. Dr. Baillarger]. Annales Médico-Psychologiques, 13(s. 7), 161-168.

Rogers, E. C. (1853). Philosophy of mysterious agents, human and mundane J. P. Jewett. Sandby, G. (1850, January.). Review of M. Alphonse Cahagnet's Arcanes de la Vie Future Dévoilés, exc. Zoist, 7(28), 414-431. http://iapsop.com/archive/ materials/zoist/zoist_v7_n28_january_1850.pdf

Schrenck-Notzing, A. F. von. (1920). Physikalische Phaenomene des Mediumismus [The physical phenomena of mediumship]. Ernst Reinhardt.

Sidgwick, H. (1895, November). Eusapia Paladino. Journal of the Society for Psychical Research, 7(123), 148-159. http://iapsop.com/archive/materials/spr_ proceedings/spr_journal_v7_1895-6.pdf

Sidgwick, Mrs. H. [E. M.]. (1915). A contribution to the study of the psychology of Mrs. Piper's trance phenomena. Proceedings of the Society for Psychical Research, 28(71), 1-657. http://iapsop.com/archive/materials/spr_proceedings/spr_ proceedings_v28_1915.pdf

Sidis, B. (1898). The psychology of suggestion: A research into the subconscious nature of man and society. D. Appleton. https://doi.org/10.1037/10578-000

Smith, J. E. (1837). Legends and miracles, and other curious and marvellous stories of human nature, collected from scarce works and ancient records. (No. 8). B. D. Cousins.

Somers, A. N. (1893, May). The double personality, and the relation of the submerged personality to the phenomena of modern spiritualism. Psychical Review, 1(4), 314-323. http://iapsop.com/archive/materials/psychical_review/ psychical_review_v1_n4_may_1893.pdf

Sudre, R. (1926). Introduction à la métapsychique humaine [Introduction to human metaphysics]. Payot.

Sudre, R. (1946). Personnages d'au-dela. Société des Éditions de Noël.

Taine, H.-A. (1878). De l'intelligence [About intelligence] (Vol. 1, 3rd rev. ed.). Hachette. Tanner, A. E. (1910). Studies in Spiritism. D. Appleton.

Tascher, P. (1855). Seconde lettre de Gros Jean à son évêque au sujet de tables parlantes, des possessions, des sibylles, du magnétisme et autres diableries [Grosjean's second letter to his bishop about talking tables, possessions, sybils, magnetism, and other devilry]. Ledoyen.

Taves, A. (1999). Fits, trances, and visions: Experiencing religion and explaining experience from Wesley to James. Princeton University Press. 
Taylor, E. (1983). William James on exceptional mental states: The 1896 Lowell Lectures. Charles Scribner's Sons.

Taylor, E. (2009). The mystery of personality: A history of psychodynamic theories. Springer.

Taylor, W. S., \& Martin, M. F. (1944, July). Multiple personality. Journal of Abnormal Psychology, 39(3), 281-300. https://doi.org/10.1037/hoo63634

Thomas, C. D. (1922). Some new evidence for human survival. W. Collins Sons.

Titchener, E. B. (1915). A beginner's psychology. Macmillan. https://doi.org/10.1037/11238-000

Treitel, C. (2004). A science for the soul: Occultism and the genesis of the German modern. John Hopkins University Press.

Troubridge, U. (1922). The modus operandi in so-called mediumistic trance. Proceedings of the Society for Psychical Research, 32(84), 344-378.

Tymn, M. E. (2013). Resurrecting Leonora Piper: How science discovered the afterlife. White Crow Books.

Van der Hart, O., \& Horst, R. (1989, October). The dissociation theory of Pierre Janet. Journal of Traumatic Stress, 2(4), 397-412. https://doi.org/10.1002/jts.2490020405

Vencio, S., Caiado-Vencio, R., \& Caixeta, L. (2018). Differential diagnosis between anomalous experiences and dissociation disorder using the Dissociative Disorders Interview Schedule (DDIS). Journal of Trauma and Dissociation, 20(2), 165-178. https://doi.org/10.1080/15299732.2018.1502715

Verrall, Mrs A. W. [M.]. (1906). On a series of automatic writings. Proceedings of the Society for Psychical Research, 20(53), 1-432. http://iapsop.com/archive/ materials/spr_proceedings/spr_proceedings_v20_1906.pdf

Viollet, M. (1908). Le Spiritisme dans ses rapports avec la folie: Essai de psychologie normale et pathologique [Spiritism and its relation with madness: Essay of normal and pathological psychology]. Bloud.

Visani Scozzi, P. (1901). La medianità [Mediumship]. R. Bemporad \& Figlio.

von Hartmann, E. (1885). Spiritism. Psychological Press.

Walusinski, O. (2014). Biographies des internes de Jean-Martin Charcot à La Salpêtrière entre 1862 et 1893 [Biographies of the interns of Jean-Martin Charcot at La Salpêtrière between 1862 and 1893]. http://baillement.com/internes/ internes_index.html

Weaver, Z. (2019, June). Julian Ochorowicz and his contribution to psychical research. Journal of Parapsychology, 83(1), 69-78.

Wolf, S. (1993). Brain, mind, and medicine: Charles Richet and the origins of physiological psychology. Transaction Publishers.

Wolf, T. H. (1973). Alfred Binet. University of Chicago Press.

Wolffram, H. (2009). The stepchildren of science: Psychical research and parapsychology in Germany, c. 1870-1939. Rodopi. https://doi.org/10.1163/9789042027299 